Ouachita Baptist University

Scholarly Commons@Ouachita

Articles

Faculty Publications

1992

\title{
Portraits of a Discipline: An Examination of Introductory Psychology Textbooks in America
}

Randall D. Wight

Ouachita Baptist University, wight@obu.edu

Wayne Weiten

Follow this and additional works at: https://scholarlycommons.obu.edu/articles

Part of the History of Science, Technology, and Medicine Commons, and the Psychology Commons

\section{Recommended Citation}

Weiten, W. \& Wight, R. D. (1992). Portraits of a discipline: An examination of introductory psychology textbooks in America. In C. L. Brewer, A. Puente, \& J. R. Matthews (Eds.), Teaching of psychology in America: A history (pp. 453-504). Washington DC: American Psychological Association.

This Article is brought to you for free and open access by the Faculty Publications at Scholarly Commons @ Ouachita. It has been accepted for inclusion in Articles by an authorized administrator of Scholarly Commons @ Ouachita. For more information, please contact mortensona@obu.edu. 


\title{
20
}

\section{PORTRAITS OF A DISCIPLINE: AN EXAMINATION OF INTRODUCTORY PSYCHOLOGY TEXTBOOKS IN AMERICA}

\author{
WAYNE WEITEN AND RANDALL D. WIGHT
}

The time has gone by when any one person could hope to write an adequate textbook of psychology. The science has now so many branches, so many methods, so many fields of application, and such an immense mass of data of observation is now on record, that no one person can hope to have the necessary familiarity with the whole.

- An author of an introductory psychology text

If we compare general psychology textbooks of today with those of from ten to twenty years ago we note an undeniable trend toward amelio-

\footnotetext{
We are indebted to several people who provided helpful information in responding to our survey discussed in the second half of the chapter, including Solomon Diamond for calling attention to Samuel Johnson and Noah Porter, Ernest R. Hilgard for emphasizing George Trumbull Ladd's importance, John A. Popplestone for underscoring John Dewey's readability, and Wilse B. Webb for noting the contributions of Frederick Rauch and James McCosh.
} 
ration of terminology, simplification of style, and popularization of subject matter.

\section{- A reviewer of an introductory text}

When were those remarks made? In the 1980s? The 1960s? Perhaps the 1940s? No, the first quote came from the preface to McDougall's Outline of Psychology, published in 1923 (p. vii). The second quote came from a 1937 review of Vaughan's (1936) General Psychology (Ewert, 1937, p. 173). These comments, which easily could have come from a contemporary author or reviewer, demonstrate that some aspects of the introductory textbook enterprise have not changed much over the years. Of course, many other facets of introductory textbooks have changed dramatically. Our portrait of 100 years of introductory psychology texts shows that they have been characterized by both stability and change.

In a 1962 review of eight introductory texts, Beardslee, Hildum, O'Dowd, and Schwartz noted that "a history of the Introductory Psychology text does not exist" (p. 123). The situation has not changed in the ensuing 30 years. The scholarly literature on introductory texts remains sparse, and the few articles available typically focus on one text or author. We hope our chapter will help to fill this void in psychology's intellectual history. In the first part of the chapter, we sketch a chronological overview of the field's most influential introductory texts. In the second part, we report on a decadeby-decade comparison of leading introductory books.

In both portions of the chapter, we discuss various forces that shaped the evolution of introductory texts. We believe that these forces fall into four broad categories. First, introductory texts have been influenced by developments in psychology, including research progress, shifting theoretical winds, and the field's expansion into new areas of inquiry. Second, because textbooks are tools for teaching, they have been molded by trends in higher education, including innovations in educational techniques, the emergence of new technologies, and changes in the composition of the student population. Third, because psychology does not evolve in a cultural vacuum, we argue that the field's textbooks have been shaped by events in society at large, including wars, economic fluctuations, and changing values. Fourth, introductory texts are influenced by developments in the publishing industry, including advances in publishing technology, competitive pressures in publishing, and the vagaries of market research. With these thoughts in mind, we begin our chronological overview of psychology's most influential introductory texts.

\section{HOW INTRODUCTORY TEXTS EVOLVED: A CHRONOLOGICAL OVERVIEW}

In an often-quoted address, James McKeen Cattell (1929) remarked that there were as many psychologists in America before the 1880 s as there 
were snakes in Ireland after St. Patrick. Nevertheless, American psychology had a rich heritage before the advent of William James's (1890) Principles of Psychology. To grasp textbook development during the past 100 years, one must examine that development against the backdrop from which it emerged. Hence, we begin with a brief discussion of how introductory psychology texts came to play a role in American higher education before the 1880s (for a more in-depth analysis, see Evans, 1984; Fay, 1939; Roback, 1964). After this discussion, we describe the major trends shaping introductory texts in a series of six overlapping periods, highlighting the field's leading texts along the way.

Psychology as Moral Philosophy (Before the 1880s)

Textbooks intended to introduce college students to the field of psychology emerged gradually out of work in moral philosophy during the 19th century. Yet, the first American textbook to contain a "sprinkling" (Roback, 1964, p. 35) of what one would recognize as psychology-specifically, Aristotelian accounts of perception, memory, and imagination - was William Brattle's Compendium Logicae. The book, a logic text written in Latin, was probably circulated in manuscript form as early as 1696 (Fay, 1939).

In 1754, Samuel Johnson, president of King's College (known today as Columbia University), published the first American philosophy textbook, Elementa Philosophica, in which he put a personal spin on the thoughts of Locke and Berkeley. Johnson differentiated natural philosophy, the study of material things, from moral philosophy, the study of spiritual things. He further divided normal philosophy into a speculative component, which included the epistemological operations of humans and, by analogy, deity, and a practical component, which included volition and feeling (Evans, 1984). Johnson's entwining of the mental and the spiritual remained a consistent theme in American academia until the late 1800 s.

In the 18 th century there was a significant increase in the influence of Scottish thought in American colleges. In 1768, while in Scotland, minister John Witherspoon accepted the presidency of the College of New Jersey (known today as Princeton University). On arriving, Witherspoon found a vibrant growth of idealism, no doubt in part a legacy of Johnson and Jonathan Edwards, and set out to eradicate it. Influenced by the work of Thomas Reid, Witherspoon attempted to realign his institution's conceptual framework with Scottish realism. Witherspoon's son-in-law, Samuel Stanhope Smith, left the family's greatest legacy to psychology with the 1812 publication of his Lectures on Moral and Political Philosophy (Fay, 1939). Smith's emphasis on inductive methods; consolidation of psychological faculties under the purview of moral philosophy; and extensive, systematic treatment of psychological topics exemplified America's psychology curriculum during the early 19 th century. 
Although these authors attempted to collect and systematize psychological information for students, primary source material was the classroom staple of the time. That was about to change, however. The period around the turn of the 19th century was a time of upheaval among students on American campuses. After the French Revolution, deism, materialism, atheism, and general irreverence for conservative values were popular among students as they became more familiar with the Jacobins, Rousseau, Voltaire, and Paine. A conservative backlash emphasizing religious fundamentalism and paternalism began to creep into classroom literature (Evans, 1984). The need for "safe" books opened the door to what Fay (1939) called the "era of American textbooks." Chief among these textbork writers was Thomas Cogswell Upham, a professor of mental and moral philosophy at Bowdoin College.

In the early 19th century, moral philosophy embraced much of what would be recognized today as the social sciences, including psychology, anthropology, sociology, and political science. A course in moral philosophy, often taught by the college president, was targeted at students completing their undergraduate degrees. The course usually had two goals: to present a rational framework depicting harmony between the natural and moral worlds and to prepare students, in light of that harmony, to face the responsibilities of civilization (O'Donnell, 1986). Writing for this course, Upham helped to shape general psychology courses as they would eventually appear (Evans, 1984). Upham published Elements of Intellectual Philosophy in 1827 and, 4 years later, enlarged it to two volumes and changed its title to Elements of Mental Philosophy (1831). The latter step was taken to reflect his combining of intellectual and sensory topics under one rubric. Despite his intellectual debt to Reid, Upham adopted an eclectic approach that embraced Scottish, English, and Continental thought in a consciously evenhanded style (Evans, 1984; Fay, 1939). According to Roback (1964), Upham provided the best textbook discussion of psychology prior to William James's Principles of Psychology.

With an influx of Kantian thought in the 1840s, other noteworthy textbooks appeared, including the first to bear the word psychology in its title: Frederick Augustus Rauch's (1840) Psychology, or a View of the Human Soul Including Anthropology. The next year a second printing appeared posthumously after the first printing sold out (Fay, 1939). Other influential texts included Samuel S. Schmucker's (1842) Psychology and Larens P. Hickok's Rational Psychology and Empirical Psychology, published in 1848 and 1854, respectively (Fay, 1939; Roback, 1964). According to Roback (1964), the first psychology texts to place bibliographic references either at the end of a chapter or at the end of the book were Francis Wayland's (1854) Intellectual Philosophy and Joseph Haven's (1857) Mental Philosophy. Mark Hopkins's (1878) An Outline Study of Man apparently was the first 
text to make extensive use of diagrams (Ofiesh, 1959). ${ }^{1}$ All of these authors had a theological slant, but they appealed to science for help in articulating the relation between theology and nature. The subject matter of psychology, they thought, provided the appropriate context for addressing these issues.

As the Civil War drew to a close, evolution fueled curricular concerns in America's institutions of higher learning, and moral philosophers found themselves in a dilemma. Moral philosophy had spent decades relating the physical, social, and spiritual domains by an empirical, commonsense account of psychological phenomena. The naturalism in Darwin's (1859) On the Origin of Species called into question any necessary relation between the physical and moral worlds. As a case against special creation developed, moral philosophers found themselves in the uncomfortable position of having adopted science as a conceptual ally only to find that science was not loyal to their assumptions. When Darwin's Descent of Man appeared in 1871, the days of soul as the cornerstone of psychological reasoning were numbered (O'Donnell, 1986). Although the old guard was reluctant to part with its notion of the soul, the stage was set for a transition to a "new" psychology.

Transition to the "New" Psychology (1880s-1890s)

The 1880 s and 1890 s witnessed an upheaval in textbook presentations of psychology, which increasingly portrayed the field as a natural science relying on laboratory experimentation to advance knowledge. James McCosh's $(1886,1887)$ two-volume Psychology had been depicted as the old tradition's last gasp in American psychology (Roback, 1964). Shortly after the publication of McCosh's second volume, his student, James Mark Baldwin (1889), broke with tradition and produced the popular Handbook of Psychology. Josef Brozek (1984) identified David Jayne Hill's (1888) Elements of Psychology as a transitional step between the passing and emerging psychologies. Although not experimental, Hill's book was congruent with new conceptions of the discipline.

Perhaps the first American textbook to use the phrase new psychology was John Dewey's highly readable Psychology, which appeared in 1887 (see Dewey, 1967). Defining psychology as the science of the facts or phenomena of self, Dewey embraced the emerging psychology in part, but he did not view psychology as an independent discipline. Although Baldwin, Hill, and Dewey contributed, the chief architects of the new psychology as portrayed in textbooks were George Trumbull Ladd and William James. Trained as a theologian, Ladd served 10 years as a Congregationalist minister before assuming responsibility for psychology at Yale in 1881 . His move to

\footnotetext{
'Hopkins was on the cusp of orthodoxy's thaw (Evans, 1984). One of his stellar students, G. Stanley Hall, remembered Hopkins's openness toward differing viewpoints (Hall, 1923), a rarity among college presidents instilling God's own truth.
} 
Yale University prompted a self-directed absorption of psychological literature. Six years of grueling work led to the publication of Ladd's (1887) Elements of Physiological Psychology. ${ }^{2}$

Ladd's text was a massive, encyclopedic summary of research that "advocated experimentation and controlled observation" and made a case for "the relevance of science to the study of mental life" (Mills, 1969, p. 103). Drawing heavily from German monographs that he struggled to translate, Ladd provided the first thorough, English-language overview of the new experimental psychology emerging from Germany, seasoned with his "American interpretation of psychological problems" (Mills, 1969, p. 103). In the first volume of the American Journal of Psychology, G. Stanley Hall (1887) wrote a favorable review of Ladd's text, predicting that it would become an indispensable handbook of the new psychology.

Although he emphasized laboratory experimentation, Ladd borrowed liberally from the traditions of moral philosophy. As Mills (1974) noted, "no one tried harder to reconcile the old and the new" (p. 299). Unable to shake his theological training, Ladd defined mind as an actual substance. This nod to a "real stuff" conception of soul elicited disappointment in some quarters (e.g., Titchener, 1921). Nevertheless, Ladd's Elements became "the standard reference work in English on physiological and experimental psychology" (Henmon, 1912, p. 239), and the text went through 10 printings before it was revised by Ladd and Woodworth in 1911.

In 1888, Ladd forwarded a copy of his book to Harvard University's William James (O'Donnell, 1986), who would soon publish a more secular portrait of psychology that would prove even more notable than Ladd's. In the opening sentence of his lengthy (1,393 pages) two-volume Principles of Psychology, James (1890) defined psychology as the science of mental life. Perhaps more to the point, in his preface James elaborated psychology's domain as a natural science of "finite individual minds" whose data include thoughts, feelings, their spatial-temporal parameters, and knowledge of these thoughts and feelings.

Thus began what may be the most influential textbook in the history of modern psychology. Some critics argued that the book was too long, too disorganized, and too saturated with James's personality to function as an effective textbook (e.g., G. S. Hall, 1891). However, these flaws were far outweighed by the book's "richness of descriptive detail" and its "boldness of explanation" that communicated to James's readers "in ways unmatched before or since, the possibilities of a scientific psychology" (Evans, 1990b, pp. 11, 28). Thus, Principles became standard reading for generations of American students.

\footnotetext{
${ }^{2}$ At the time, the expression physiological psychology was used interchangeably with experimental psychology to refer to the emerging experimental laboratory science of psychology (Hilgard, 1987). Ladd's text contained extensive discussion of biological topics, but it included many other topics as well, and it was not a physiological psychology text in the modern sense.
} 
Although his text contained extensive citations of experiments, James was not particularly intrigued by laboratory work. He thus wrote a scientific, but not an experimental, psychology text. As Evans (1990b) observed, James, like Wundt, was a transitional figure, spanning the shift from 19thcentury philosophical psychology to the new psychology. James helped to lay the foundation for psychology as a natural science. According to Taylor (1990), James intended to fuse German, French, and English laboratory work into a scientific tool to replace the metaphysical approach that previously dominated psychology.

The naturalism in James's (1890) Principles probably represented America's first secular psychology (Evans, 1991). However, this secularization had its critics. In particular, Ladd (1892) assailed James's failure to acknowledge the full metaphysical complexities of psychological subject matter and his implicit assertion of an unwarranted metaphysical position (Giorgi, 1990). Ladd praised the book's style but complained that to avoid metaphysics, James had identified psychological explanation too closely with brain states. James's alignment of consciousness with brain function constituted a metaphysical assumption and belied any claim of psychology as a natural science. James (1892a) acknowledged the validity of Ladd's argument but wrote that "I wished by treating Psychology like a natural science, to help her become one" (p. 146). James went on to argue that although many metaphysical topics were interesting, psychology would do well to limit its concern to events in time and space.

Their later activities suggest that Ladd and James had different feelings about the experience of writing an introductory text. Ladd, who has been called the "great textbook writer" (Mills, 1974), apparently relished the experience, as he revised his Elements of Physiological Psychology (Ladd \& Woodworth, 1911) and went on to write four other introductory texts: Outlines of Physiological Psychology (1890), Primer of Psychology (1894a), Psychology: Descriptive and Explanatory (1894b), and Outlines of Descriptive Psychology (1898).

By contrast, James endured a sometimes torturous 12-year struggle to complete Principles. His delays (the book was originally supposed to be finished in 1880) occasioned a number of rancorous exchanges with his publisher, Henry Holt (Benjamin, 1990). Although Holt prevailed on James to prepare an abridged version of Principles titled Psychology, Briefer Course (1892b), he never convinced James to revise either book, despite the books' great success. Why? Benjamin (1990) argued "that James found the whole introductory psychology textbook business a little unsavory" (p. 4). ${ }^{3}$ Support

\footnotetext{
${ }^{3}$ At the 1990 meeting of the Eastern Psychological Association, Ludy T. Benjamin (1990) presented a delightful, tongue-in-cheek account of William James's disillusionment with the enterprise of textbook writing. The narrative of Benjamin's address is contained in the minutes of that meeting (see Benimoff, 1990).
} 
for this view comes from an 1891 letter concerning Psychology, Briefer Course, in which James wrote to Holt:

By adding some twaddle about the senses, by leaving out all polemics and history, all bibliography and experimental details, all metaphysical subtleties and digressions, all quotations, all humor and pathos, all interest in short, and by blackening the tops of all the paragraphs, I think I have produced a tome of pedagogic classic which will enrich both you and me, if not the student's mind. (H. James, 1920, p. 314)

Thus, it appears that James became highly cynical about commercial publishing. Although the writing careers of Ladd and James diverged, both used their introductory texts to articulate influential visions of what psychology should be. Later authors of introductory texts tried to emulate this accomplishment, with varying degrees of success, for several decades.

\section{Dueling Systems: The Era of Theoretical Treatises (1890s-1920s)}

As the new science of mental life grew, debate increased about the definition, boundaries, and methods of psychology. Schools of thought and the theoretical systems that they spawned played an increasingly important role. Thus, from the 1890 s through the 1920s, authors typically used introductory texts to stake out their theoretical views.

Prominent among these early systematists was Edward Bradford Titchener of Cornell University. Working under the assumption that "the main thing in teaching elementary psychology is to give one's pupils a system, a consistent body of doctrine" (Titchener, 1899, p. viii), he waded into the textbook market with An Outline of Psychology (Titchener, 1896, 1897, 1899). Titchener considered the descriptive, nonexperiential, unsystematic, mental function psychology of Dewey, Ladd, and James, although an advance from moral philosophy, to be little more than "muddle" (Evans, 1990a). To Titchener, muddle resulted from mindlessly mixing the perspectives of common sense, science, and technology in one's analysis of phenomena. Titchener intended to establish psychology as an experimental science independent of philosophy.

Titchener (1896) defined psychology as the science of mental processes. He supported other psychological endeavors, with Margaret Floy Washburn's animal psychology being a prime example (Evans, 1990a). However, when Titchener wrote the word psychology he meant his psychology: introspective, experimental, normal adult psychology. Although he viewed child psychology, psychopathology, and social psychology as legitimate enterprises, these applied topics were not covered in his books, which focused solely on "pure" experimental psychology (i.e., sensation, perception, association, memory, motivation, emotion, and thought).

Titchener's Outline of Psychology, modeled after a German text pub- 
lished in 1893 by a close colleague from his Leipzig days (Külpe, 1893/ 1909), reduced all psychological data to direct sense-experience and sought to examine these data along the attributes of quality, intensity, duration, extent, and clarity. This tack left no room for functional or volitional considerations. The 1899 edition of his Outline found Titchener more precisely delineating the lines of argument between the camps of structuralism and functionalism.

A prolific writer, Titchener $(1898,1910,1915)$ eventually wrote three other introductory texts. Although these were well received, his most influential textbook - perhaps the preeminent text of the early 20th century-was his two-volume Experimental Psychology (Titchener, 1901-1905). To be a true science, psychology needed the controlled observations afforded by the laboratory. Evans (1990a) maintained that these volumes, referred to as Titchener's "manuals," were the principal catalyst that moved American psychology from philosophical inquiry toward experimental investigation and that they established the experimental component of the American undergraduate psychology curriculum. After writing the manuals, Titchener decided that further revision of his Outline was futile. In 1910, he produced an entirely new introductory book titled A Text-book of Psychology. Less polemical than its forerunner, this book was written expressly for classroom use, but it was not an "easy" text (Holt, 1911; Watson, 1911).

The most prominent functionalist introduction to psychology was Psychology: An Introductory Study of the Structure and Function of Human Consciousness by James Rowland Angell $(1904,1908)$ of the University of Chicago. Angell (1936, p. 21) stated in his autobiography that he cut his "psychological teeth" on Dewey's Psychology, which was published in 1890. On encountering James's Principles and contrasting the two texts, Angell (1936) related being "breathless and excited as one may imagine feeling after coming through a great storm, or an earthquake" (p. 22). Angell adopted Psychology, Briefer Course as he began to teach but found James's style cumbersome-hence, the impetus for writing his own text.

The imprint of functionalism was also seen in other widely used introductory texts of the period, such as Walter B. Pillsbury's (1911) Essentials of Psychology. Although Pillsbury's text was apparently the first to define psychology as the science of human behavior, his "novel definition" did not appreciably alter his largely functionalist approach (Cameron, 1911). The functionalist banner was carried into the introductory texts of the 1920s by Harvey Carr's (1925) Psychology: A Study of Mental Activity.

Behavioral approaches to psychology were numerous and growing when Watson's (1913) influential "manifesto" appeared. Watson did not singlehandedly create behaviorism, but he was its most prominent champion (O'Donnell, 1986). Watson's (1919) Psychology from the Standpoint of a Behaviorist was a thoroughly behavioral introduction to psychology incorporating the terminology of Pavlov and the conceptualizations of Bechterev. 
However, two decades after the birth of behaviorism, Pillsbury (1932) credited Max Meyer's (1911) Fundamental Laws of Human Behavior with solidifying the behavioral perspective. The behavioral tradition was later carried forward by John Frederick Dashiell's (1928) Fundamentals of Objective Psychology.

Structuralism, functionalism, and behaviorism were not the only approaches to psychology that generated expositions in introductory textbooks. In her first text, Mary Whiton Calkins (1901) defined psychology as the science of mental events and conscious self, but her second text (Calkins, 1910) focused squarely on her self psychology (Furumato, 1991). William McDougall $(1912,1923)$ mounted a spirited defense of his hormic psychology in his texts. In 1911, Robert Mearns Yerkes's Introduction to Psychology, a thinly disguised apology for the comparative method (Wight, 1991), was published. Applied psychology received exposure in Hugo Münsterberg's (1915) introductory text.

\section{Shift Toward Theoretical Eclecticism (1920s-1930s)}

The theoretical debates among different schools of thought in psychology gradually became less vitriolic. This trend was reflected in introductory texts, which began to manifest a more eclectic character. As Beardslee et al. (1962) put it, there was a "shift from system orientation to cafeteria orientation" (p. 124). Introductory texts with an explicit theoretical slant never disappeared completely, but by the 1930s most of the leading texts were presenting many conflicting viewpoints, which were ostensibly accorded roughly equal importance.

To some extent this shift was more illusory than real; many authors professed more eclecticism than their textbooks revealed. In a review of a text purporting to be eclectic, Geldard (1936) noted that

as to the matter of indoctrinating the student, it must be recognized that there is more than one way of setting up a metaphysical bias. . . . Textbook writers therefore, unless they seek a stupid catholicity, must indoctrinate. The device, here as elsewhere, is editorial inclusion and exclusion. (p. 694)

Thus, the overt, openly acknowledged theoretical bias of earlier books was replaced with a more subtle, undisclosed bias cloaked in the disguise of eclecticism. The newer texts were genuinely more eclectic than their predecessors, but the change was a matter of degree.

In 1921, Columbia University's Robert Sessions Woodworth published an introductory book that eventually "outsold all other texts so greatly as to be beyond competition" (Boring, 1950, p. 565). Woodworth's Psychology: A Study of Mental Life was one of the first introductory texts to display an eclectic bent. A decade earlier, Woodworth had written most of the 1911 
revision of Ladd's classic Elements of Physiological Psychology (Mills, 1974). In a sense, then, the mantle of the "great textbook writer" was passed from Ladd to Woodworth.

Using a colloquial writing style, Woodworth $(1921,1929,1934,1940$; Woodworth \& Marquis, 1947) authored a wide-ranging survey that enjoyed enormous popularity from the 1920 s through the 1940 s. Woodworth asserted that he had no allegiance to a specific school of thought, but his portrait of psychology bore the mark of functionalism. In a review of Woodworth's (1934) third edition, McGeoch (1936, p. 179) noted the following:

Controversial systematic issues are avoided in this panscholasticism, but there runs through it the constant thread of Woodworthian dynamic psychology, presented without argument and often implicitly. There is a functional system here; it is unnamed and loosely knit, but its outlines are clear. (p. 179)

It is hard to say whether the commercial success of Woodworth's text was attributable to its supposed eclecticism, its interesting and conversational writing, or its lucid portrait of the field. Whatever the case, other authors were soon imitating Woodworth's professed eclecticism.

The importance of Woodworth's text and its various revisions cannot be overestimated. According to Winston $(1988,1990)$, Woodworth's introductory text-and his more advanced Experimental Psychology text (Woodworth, 1938; Woodworth \& Schlosberg, 1954) — played a crucial role in reshaping psychology's conceptions of experimentation and causality. The notion that an experiment requires the manipulation of an independent variable while other variables are held constant, and the related notion that causal relations can be revealed only through this experimental method, were not always as widely accepted as they are today. Woodworth did not originate this positivist view; it emerged gradually in psychology during the early 20th century (Danziger, 1979, 1985). However, Woodworth contributed mightily to popularizing this view, which he first articulated in the 1934 edition of his introductory text. Woodworth's texts, which were read by generations of students and professors, exerted considerable influence over the directions taken by psychology during the 1940s, 1950s, and 1960s (Winston, 1988, 1990). Although contemporary psychologists increasingly recognize that causal inferences can be derived from nonexperimental, multivariate methods, introductory textbooks continue to present Woodworth's simpler conception of the connection between experimentation and causality (Winston, 1988).

During the 1930s, the shift toward eclecticism was apparent in many introductory texts besides Woodworth's. For example, the strong behavioral orientation in Dashiell's (1928) Fundamentals of Objective Psychology was replaced in 1937 with a more evenhanded treatment and a less parochial title, Fundamentals of General Psychology. The emerging eclecticism was not 
greeted with enthusiasm in all quarters. In a review of Dashiell's 1937 edition, Marquis (1938) complained that "whereas the former edition was frankly and courageously polemical in its behavioristic point of view, the new edition has sacrificed consistency to eclecticism" (p. 96).

The shift toward eclecticism, which undermined the notion that texts should be written with a consistent viewpoint, facilitated the rise of the "team approach" to writing introductory texts. Arguing in their preface that one person could no longer stay well informed about the rapidly expanding science of psychology, Edwin G. Boring, Herbert S. Langfeld, and Harry P. Weld (1935) coauthored the field's first team text, Psychology: A Factual Textbook. Boring, Langfeld, and Weld, who were at Harvard University, Princeton University, and Cornell University, respectively, served as editors for a team of 16 specialists who wrote initial drafts for chapters in their areas of expertise.

The team approach was later emulated successfully by Clifford Morgan (1956) and a crew of 14 contributors. The team concept might have reached its zenith in 1969, when 38 psychologists contributed to the first edition of Psychology Today (CRM Books, 1969), although one might also cite 1977, which saw the publication of a 9-author text (Weiner et al., 1977) and a 10-author text (Mussen et al., 1977). Contemporary professors often complain that "committee-authored texts" suffer from uneven coverage, conceptual discord, and stylistic inconsistency. However, reviews of the Boring et al. (1935) text suggested that the editors successfully infused the specialists' chapters with a reasonably uniform writing style and conceptual orientation (e.g., Geldard, 1936).

In their preface, Boring et al. (1935) asserted that the "facts of psychology should be presented to the young student of psychology in terms free from the bias of metaphysical presuppositions or of psychological systems" (p. vii). Although they formally embraced the eclectic approach, two of the three editors and many of the contributors had been trained in the Titchenerian tradition, and reviewers noted that the book reflected this bias toward "pure" psychology (e.g., Bentley, 1948; Dimmick, 1940; Geldard, 1936; Hunter, 1935).

Boring, Langfeld, and Weld issued new editions of their successful text in 1939 and 1948. Both editions involved substantial revisions that merited new titles (Bentley, 1948; Webb, 1991). Citing pedagogic reasons, the authors rearranged the order of topics in their second edition, moving social psychology and personality to the front of the book and sensation to the back. In the third edition, the order of topics was shuffled again and the book doubled in size, taking on an encyclopedic character. The Boring et al. text was a demanding, no-nonsense introduction to psychology that generally did not cater to students' interests and preferences (Hunter, 1939). Although Boring et al. remained loyal to this approach through all three 
editions, many competing books soon became student-oriented, thanks to the success of Ruch's (1937) Psychology and Life.

\section{Rise of Student-Oriented Texts (1930s-1940s)}

The pragmatism engendered by the Great Depression, the gradual emergence of applied psychology, and the influx of more career-oriented middle-class students into higher education probably set the stage for the rise of student-oriented introductory texts. The first influential text of this genre was Psychology and Life by Floyd L. Ruch (1937) of the University of Southern California. The essence of Ruch's (1937) approach is summarized in the preface to his first edition:

I do not know exactly how many textbooks in elementary psychology have been written in the past thirty-five years. These books were written in loyalty to something. All of them were dedicated to psychology: some to psychology as a science; some to psychology as an exact science; others to the author's system, or to the author's favorite professor's system. I have not seen a textbook of elementary psychology written under a vow of loyalty to the student. . . . I am not condemning these practices. I have at times even praised them. I should merely like to indicate that this textbook in elementary psychology has, rightly or wrongly, been differently conceived. (p. v)

How did Ruch make his book more student oriented than its contemporaries? To accomplish this goal he (a) expanded coverage of topics that students found interesting and compressed coverage of less popular topics; (b) transposed the traditional order of topics by moving the more accessible material to the front; (c) used an "easy personal style" of writing and a "slightly dramatized method of presenting facts" (Buel, 1938, p. 92); (d) introduced a personal adjustment slant that emphasized the application of research and theory to students' everyday lives; and (e) increased the number and prominence of photographs to create an attractive look.

In a review of Ruch's first edition, Buel (1938) enthusiastically concluded that "from the student's point of view, it is probably the most interesting and readable textbook that has been offered in psychology" ( $p$. 92). Some of the features of Ruch's text (e.g., the personal writing style and the rearranged topical organization) had been seen before, but no previous author had put so many student-oriented features together in one book.

Like other introductory texts of the 1930s, Ruch's book was theoretically eclectic, but in other ways it was a radical departure from existing norms. He was the first author to discuss (in his preface) the use of market research to ascertain students' and professors' topical preferences. Breaking with tradition, he completely eliminated coverage of the nervous system. 
Unlike his contemporaries, Ruch was not bashful about providing students with practical advice, and he tackled a host of topics that others had been loath to touch, including communism, "crushes," friendship, homosexuality, strikes, marital strife, and study skills.

Ruch's bold experiment drew mixed reactions. Many professorsenough to make the book a great commercial success - responded favorably to the new approach, but many others disliked the notion of catering to students' tastes. In an influential article on the introductory course, Wolfle (1942) argued that

the mere fact that students find a topic interesting is never justification for including it in the course. . . Selecting course material to accord with student interest invites the charge that one is "popularizing" the course. By popularizing, the critic usually means cheapening. (p. 695)

In the preface to his second edition, Ruch (1941) acknowledged that the "consensus has been that the writer succeeded rather better in meeting the interests of the students than in developing a uniformly high level of critical scientific thinking" (p. vi). To increase the second edition's scientific rigor without sacrificing student interest, he made a number of concessions to tradition (Buel, 1942). Among other things, he abandoned elaborate photo essays, added two chapters on the brain and nervous system, moved toward a more conventional topical sequence, and bolstered coverage of traditional topics. However, the second edition still emphasized appealing topics, personal adjustment, and friendly writing.

These emphases have been carried through 11 more editions of Psychology and Life by Ruch (1948, 1953, 1958, 1963a, 1967a) and his eventual successor, Philip G. Zimbardo of Stanford University (Ruch \& Zimbardo, 1971; Zimbardo \& Ruch, 1975; Zimbardo, 1979, 1985, 1988, 1992). Zimbardo has maintained Ruch's commitment to engaging writing, intriguing topical coverage, and the application of research and theory to social problems and everyday life while gradually making the book more rigorous and encyclopedic. His revisions have earned high marks from reviewers (e.g., Allen, 1980; Campbell, 1976; Cone, 1976; Heatherington, 1986; Sexton, 1977), and Psychology and Life has retained its place among the most widely used introductory books for more than 50 years, a remarkable tribute to Ruch's vision of what an introductory text should be.

Ruch's (1937) first edition sparked a dramatic transformation of introductory psychology texts. Most authors felt compelled to make their texts at least somewhat student oriented. Even the authors of established, traditional texts such as Boring, Langfeld, and Weld (1939) and Woodworth (1940) scrambled to incorporate applied topics to make their books more inviting. The most successful new text of the 1940s, Psychology: The Fundamentals of Human Adjustment by Norman L. Munn (1946) of Bowdoin College, also aspired to this goal. Although less student oriented than Ruch, 
Munn (1946) encouraged the reader to "look upon this as a book about yourself" (p. xi). Like Ruch, Munn wrote an eclectic book that added coverage of personal adjustment issues and relegated sensation and perception to the back of the book. His widely adopted text went through numerous revisions over a 40-year period that eventually saw a change in title, the addition of collaborators, and movement to a new publisher (Munn, 1951, 1956, 1961, 1966; Munn, Fernald, \& Fernald, 1969, 1972; Fernald $\&$ Fernald, 1978, 1985). The approach of Ruch and Munn gradually became the dominant model for introductory texts. Even research-oriented texts began to borrow some of their strategies for enticing students' interest.

Advent of Encyclopedic Texts (1950s-1960s)

Subsequent trends in introductory texts were more subtle than the major shift triggered by Ruch. The next discernible trend was a move toward more encyclopedic texts. The 1950s and 1960s were a period of expansion, prosperity, and boundless optimism for higher education. Academicians' contributions to the war effort inspired a new faith in the value of scientific research, which colleges embraced with increased vigor. Psychology departments sought to obtain grants, foster research, win recognition, and enhance their prestige. In this climate, psychological research expanded at a rapid pace. Consequently, the authors of many introductory texts began to compete for respect and adoptions by covering more research on more topics in more detail. As a result, the leading texts increased in words, pages, and references cited.

This metamorphosis was gradual and unannounced. Whereas Ruch had proudly declared his resolve to write a new type of text, no one openly proclaimed a decision to make introductory texts more comprehensive and encyclopedic; it just happened. Thus, it is difficult to pinpoint one book that launched the trend toward encyclopedic texts. However, two prominent texts, first published in the 1950s, clearly contributed: Introduction to Psychology by Hilgard $(1953,1957)$ and Elements of Psychology by Krech and Crutchfield (1958).

Ernest R. Hilgard (Stanford University), who was thanked for "many helpful criticisms and suggestions" in the preface to Ruch's (1937, p. ix) first edition, set out to write an eclectic, comprehensive text that would appeal to students and professors. According to Finger (1954), Hilgard tried to achieve these seemingly incompatible goals by covering topics of current interest to psychologists while accommodating students' desires for personal insights. The first edition received largely favorable reviews (e.g., Finger, 1954; Krech, 1954), but feedback from adopters led Hilgard (1957) to tilt the balance of the second edition back toward professors. He added new chapters on physiology, sensation, and statistics and a new feature: separate 
"critical discussion" sections that ac, ssed controversial theoretical issues in some detail.

Hilgard apparently was the fi: i author to discuss the number and recency of his references in his preface, a practice that many others soon copied. Hilgard's (1957) second edition grew to approximately 300,000 words and more than 900 references (roughly double the number found in a typical 1940s text). In the third edition (Hilgard, 1962), the number of references increased to around 1,500 and reviewers noted that "the sheer quantity of material in this volume is staggering" (Bare \& Guthrie, 1963, p. 184). Later editions (Hilgard \& Atkinson, 1967; Hilgard, Atkinson, \& Atkinson, 1971, 1975; Atkinson, Atkinson, \& Hilgard, 1979, 1983; Atkinson, Atkinson, Smith, \& Hilgard, 1987; Atkinson, Atkinson, Smith, $\&$ Bem, 1990) continued to enjoy a reputation for "scholarly sophistication," "extensive coverage," and "plain language" (Pfeiffer, 1980, p. 119) and the text became "one of the most widely used books in the history of college publishing" (Atkinson et al., 1990, p. v).

The largest and most encyclopedic introductory text published in the 1950s probably was Elements of Psychology by David Krech and Richard S. Crutchfield (1958) of the University of California. It had 25 chapters, 736 pages, and roughly 340,000 words. The second edition (Krech, Crutchfield, $\&$ Livson, 1969) grew to nearly 900 pages and 50 chapters, and the fourth edition (Krech, Crutchfield, Livson, Wilson, \& Parducci, 1982) topped 400,000 words (Weiten, 1988).

Krech and Crutchfield's (1958) first edition contained innovative "boxes" that had a dramatic impact on later books. Their 169 boxes provided relatively detailed discussions of empirical research on specific topics. The idea of highlighting in-depth digressions was not entirely new; Hilgard (1957) had introduced a similar feature a year earlier. However, Krech and Crutchfield's boxes garnered more attention and accolades from reviewers (e.g., Archer, 1959; Bartlett, 1959), and boxes eventually became a staple of introductory texts in the 1970s and 1980s. Boxes are still common, although they have been criticized as disruptive (e.g., Thomas, 1984), and their use appears to be declining.

The trend toward encyclopedic texts was apparent in many other widely used books of the 1950 s and 1960s. In 1956, Clifford T. Morgan wrote a hefty 676-page overview of the field that grew to 816 pages in its third edition (Morgan \& King, 1966). Gregory A. Kimble (1956) published a more modest 400-page survey of the field, but his second and third editions (Kimble \& Garmezy, 1963, 1968) mushroomed to 655 and 756 pages, respectively. The 1960 s also brought the publication of lengthy, comprehensive first editions by Kendler (1963), McKeachie and Doyle (1966), and Kagan and Havemann (1968). Already established books also swelled dramatically during this period. For example, Ruch's text grew from 492 
pages in 1953 to 758 pages in 1967, and Munn's grew from 497 pages in 1946 to 812 pages in 1961 .

Not all influential texts of the 1960 s were encyclopedic. For instance, Donald O. Hebb's $(1958,1966)$ compact text contained 256 pages in the first edition and 353 pages in the second. A throwback to the systematic theoretical treatises of earlier decades, Hebb's Textbook of Psychology was widely lauded (Bartlett, 1959; McKenna, 1967) but less widely used.

The emergence of encyclopedic texts eventually stimulated a counterbalancing trend: the publication of abridged versions of lengthy books. Condensed introductory texts had a rich ancestry, as both Ladd (1890) and James (1892b) published brief versions of their classic books, but abridged editions had not been seen for many decades. Munn (1962) and Ruch (1963b) were the first to release condensed editions in the 1960s. Kendler and Kendler (1971), McKeachie and Doyle (1972), and Morgan (1974) eventually followed suit. Even the size of these abridged editions underscored the modern trend toward encyclopedic texts. For instance, Munn's (1962) "brief" edition contained 588 pages and Ruch's (1967b) had 606. Nevertheless, condensed editions clearly filled a need for some professors and became commonplace by the 1980 s.

Era of Artwork, Pedagogy, and Homogenization (1970s-1980s)

Eclectic, encyclopedic, student-oriented books continued to prevail during the 1970s and 1980s, but efforts to increase student appeal led to some basic changes. The most prominent changes were the growth of elaborate illustration programs and increased reliance on pedagogical devices.

The late 1960 s and early 1970 s were a period of turmoil on many college campuses, as students protested against racial discrimination and the Vietnam War. Emboldened by their success in the political arena, students began to demand more self-determination in course selection, more "relevance" in the curriculum, and more influence (through course ratings) on evaluations of their professors. As general education requirements were reduced, many academic departments were forced to compete for enrollments. In response to these pressures, many professors worked to make their courses more appealing for students. One result of this effort was the need for slick, flashy, magazinelike textbooks.

This need was filled in 1969 with the arrival of Psychology Today (CRM Books, 1969), a visually stunning text from a publisher that had recently launched a general circulation magazine of the same name. Reasoning that college students would respond to the snazzy graphics that made the magazine a success, CRM modeled its text after its magazine. With the assistance of James V. McConnell, a team of editors and writers attempted to weld the divergent contributions of 38 consultants into a coherent overview of the field (McConnell, 1978). Reviewers characterized the first edition as 
uneven, unbalanced, and poorly integrated (Brown et al., 1971), but these complaints did not impede the book's acceptance. It was a huge commercial success, selling 186,000 copies the year it was released (Kadushin, 1979). ${ }^{4}$

Psychology Today (CRM Books, 1969, 1972; CRM/Random House, 1975, 1979) was far more heavily illustrated than its competitors, brashly decorative, and four colors throughout. The book's uneven discourse was smoothed out to some extent in later editions (Kasschau \& Camp, 1976; Walls, 1980). After the fourth edition, the text was ostensibly taken over by a conventional author team (Bootzin, Loftus, Zajonc, \& Hall, 1983; Bootzin, Bower, Zajonc, \& Hall, 1986; Bootzin, Bower, Hall, \& Crocker, 1991). Although some critics questioned the educational value of its lavish illustration program (e.g., Abma, 1974), Psychology Today snared many adoptions, and competing publishers eventually embraced elaborate fourcolor illustration programs, which became the norm for introductory texts by the mid-1980s.

Innovative graphics were not Psychology Today's only claim to fame; it was higher education's first "managed" text-conceived, designed, and composed by a team of editors and professional writers. Many professors are used as consultants, but the book's contents are closely guided by market research and carefully controlled by the publishing house (Kadushin, 1979). Some of the academic consultants may be listed as authors, but they do not actually write the book and they do not have an author's normal control over its content. Managed texts had long been common in elementary and secondary education, but they were new to higher education.

The managed text created a furor. Professors raised concerns about popularization and plagiarism by professional writers and they bemoaned their loss of control over the content of the discipline's texts (see Fischer \& Lazerson, 1977; Kadushin, 1979; McMahon, 1977; P. W. Robinson \& Higbee, 1978). Given the success of Psychology Today, many academicians feared that managed books would come to dominate the introductory course, but their fears proved unfounded. The weaknesses of the managed textuneven coverage, lack of an author's "voice," mediocre scholarship, and bland mimicry of other books - gradually became apparent, and later managed texts did not duplicate the success of Psychology Today (Kadushin, 1979; McMahon, 1977). The 1980s saw some publishers continue to use the managed text model, but it did not achieve the market dominance that academicians once feared.

In addition to flashy graphics, the 1970s brought increased use of pedagogical aids. This trend was probably attributable to growing concern about the decline of students' academic skills. The 1960s and 1970s were

\footnotetext{
${ }^{4}$ Although sales of this magnitude were not unprecedented, they were remarkably high. Introductory psychology texts that sell more than 40,000 copies in their first year are considered to be commercially successful.
} 
a time of rapid expansion for higher education. The nation's undergraduate population tripled between 1960 and 1980, as community colleges attracted greater numbers. This growth brought more underprepared students into classrooms, along with more "nontraditional" students whose family and work responsibilities strained their commitment to diligent study. As professors increasingly complained about students' mediocre study skills and divided commitments, a new emphasis was placed on pedagogy. Although several learning aids (e.g., chapter summaries, chapter outlines, and glossaries) were used in many popular books by the 1960s, the 1970s brought a host of new pedagogical devices.

The increased emphasis on pedagogy was apparent in many texts, but James V. McConnell's (University of Michigan) Understanding Human Behavior in 1974 probably led the way. In the preface to his first edition, McConnell (1974) noted that he "realized that none of the major texts available were actually written in collaboration with the students," so he set out to write a text "for, about, and with considerable help from students themselves" ( $p$. iii). He obtained this assistance by asking his students to critique chapter drafts. They responded with more than 25,000 individual comments, thus providing McConnell with a rich lode of feedback that helped him to assemble an interesting, student-oriented text (Caffrey, 1978; Kasschau, 1974).

McConnell's (1974, 1977, 1980, 1983, 1986, 1989) eclectic, encyclopedic text introduced three innovative pedagogical devices: a page-bypage running glossary, a pronunciation guide for technical terms, and fictional anecdotes to engage interest. McConnell also catered to students' preferences by doing away with the extensive citations and references that had become dense and voluminous in most competing books.

Other introductory texts also tried to "up the ante" for pedagogical aids during the 1970s. For example, Bourne and Ekstrand (1973) used cartoons and boxed-off newspaper clippings on psychological issues to spark students' interest. Several authors began to insert study-guide exercises (fillin-the-blank, matching, multiple-choice questions, etc.) into the texts themselves (e.g., Coon, 1977; Davidoff, 1976; Vernon, 1974). The 1970s also brought the first use of chapter learning objectives (e.g., Lefton, 1979) and the first book (Coon, 1977) organized around F. P. Robinson's (1970) SQ3R study method. The increased emphasis on pedagogy was reflected in the book reviews of the period, as reviewers in Contemporary Psychology started to include charts comparing introductory texts' learning aids (e.g., Brown et al., 1971; Cone, 1976; Kasschau, 1973, 1977). During the 1970s, extensive pedagogical aids were seen mostly in texts designed for the "lower level" of the introductory market, but many of these learning aids began to creep into "upper-level" texts in the 1980s.

This new emphasis on pedagogy also spawned extensive discussions of introductory texts' readability, usually as measured by the formula de- 
veloped by Flesch $(1948,1951)$. Although an article comparing popular texts' readability was published as early as 1954 (Ogdon, 1954), the 1970s brought a flurry of such articles (Gillen, 1973, 1975; Gillen, Kendall, \& Finch, 1977; Quereshi \& Sackett, 1977; Quereshi \& Zulli, 1975), and reviewers began reporting Flesch readability (and human interest) estimates (e.g., Abma, 1974; Brown et al., 1971; Cone, 1976; Kasschau, 1973, 1977). The attention devoted to readability measures incited a furor, as many psychologists (Chatman \& Goetz, 1985; Croll \& Moskaluk, 1977; Griesinger \& Klene, 1984; Landrigan \& Palladino, 1974) and reading researchers (Bruce, Rubin, \& Starr, 1981; Lange, 1982; Maxwell, 1978) raised doubts about the validity and value of Flesch estimates. This criticism presumably contributed to the diminished interest in readability estimates in the $1980 \mathrm{~s}$.

Authors' and publishers' commitment to pedagogy also fueled increased competition to provide professors and students with more and more elaborate ancillary packages. During the 1960s, publishers typically furnished adopters with an instructor's manual, test bank, slides, and transparencies. However, in the 1970s and 1980s, publishers started giving away larger instructor's manuals, extra test banks, more slides and transparencies, adopter newsletters, booklets designed to improve students' critical thinking or study skills, computerized test banks and grade books, computerized study guides, computer simulations, reference databases on computer diskettes, audiotapes, films, videotapes, video laser disks, telephone test preparation, educational board games, and replicas of Time magazine and the New York Times that contained reprints of psychology-related articles. Whether one viewed these ancillaries as valuable teaching and learning tools or superfluous contrivances, they clearly drove up the prices of introductory texts (Griggs \& Jackson, 1989; Sommer, Estabrook, \& Horobin, 1988).

As competitive pressures led publishers to underwrite expensive graphics and photograph programs, four-color production, elaborate advertising brochures, and a growing plethora of free ancillaries, the investment required to produce an introductory text skyrocketed. As the financial stakes climbed, publishers sought to reduce the risk of a commercially unsuccessful book. Hence, editors turned more and more to market research, surveying professors about their topical priorities, pedagogical preferences, and needs for ancillaries. With their profits squeezed by the acceleration of used-book sales, publishers seemed to become more conservative about deviating from the modal preferences uncovered in their research. The unfortunate result was a growing homogenization of introductory texts (see Farnsworth, 1979; Gould, 1988). ${ }^{5}$

\footnotetext{
'The increased consolidation of the textbook publishing industry also might have contributed to this growing homogenization. The 1980s saw a rash of mergers in the industry, which left fewer and fewer independent companies. Many midsize American publishers were absorbed into giant, international conglomerates (Rudman, 1990). Midway through this consolidation, Apple (1985) reported that the 10 largest textbook companies controlled $75 \%$ of all sales (the percentage is probably higher today). Some of the newly formed conglomerates found themselves with 10 or more introductory psychology texts, which often shared editors, designers, art programs, and ancillaries.
} 
Concern about the growing similarity of introductory texts was voiced as early as 1962 (Beardslee et al., 1962), but the late 1970s and early 1980s brought complaints (e.g., Fretz, 1979; Jacobs, 1984; Popplestone, 1978; Thomas, 1984). In one review, Thomas (1984) asked why anyone would bother to write yet another introductory text, given that "there appear to be more than an adequate number of texts from which to choose, and the difference between texts often does not exceed the famous jnd (just noticeable difference)" (p. 629). In another review, Jacobs (1984) chided publishers for making their texts too similar, arguing that "there is no compelling reason for all of our introductory books to be spin-offs of one or two popular texts. Trying something different in approach, emphasis, or coverage would enrich the choices available to the instructors and students" (p. 467). Although it is easy to criticize authors and publishers for their reluctance to try something different, they are responding to the realities of the marketplace. Most texts that deviated substantially from the norm in the 1970s and 1980s were commercial failures. For instance, Gazzaniga (1973), Lazarus (1974), Brown and Herrnstein (1975), Malott and Whaley (1976), Levin (1978), Pollio (1981), and Doyle (1987) all wrote refreshingly different texts that did not win enough adoptions to merit a second edition. Thus, teachers share responsibility for the growing homogenization of introductory texts.

Homogeneity is a subjective concept, and it would be an oversimplification to write off the successful texts of recent years as nothing more than clones of one another. Many excellent new texts were published in the 1980s and some of them broke new ground. For example, Henry Gleitman's (1981) "virtuoso explanations of complex ideas" (T. H. Carr, 1982, p. 356) allowed him to take the level of discourse in introductory texts to a new high while returning to traditional topical coverage more reminiscent of the 1940s than the 1980s. One reviewer (Gerow, 1981) asserted that "Gleitman's effort is as close to a truly new and scholarly treatment of general psychology as we have seen in many years" (p. 189). David G. Myers (1986) broke new ground with a superb illustration program that was more didactic than decorative and a witty, elegant writing style that was widely lauded (Griggs, 1990).

The 1980s also saw a reemergence of women as authors of leading introductory texts. After Mary Calkins's $(1901,1910)$ time, female authors of successful introductory texts were rare and virtually all of them worked with male collaborators. We can only speculate as to why female authors were conspicuous by their absence for so many years. Surely, there were female psychologists who were willing and qualified to write their own texts. Perhaps publishers felt that texts had to have at least one male author to be taken seriously. In any case, the 1980s brought three highly successful new texts written exclusively by women. Camille B. Wortman and Elizabeth F. Loftus (1981) wrote a lean, no-nonsense book that bucked the widespread 
tendency to load introductory texts with gimmicks and titillating topics; Diane E. Papalia and Sally W. Olds (1985) published a well-written, comprehensive portrait of psychology; and Carole Wade and Carol Tavris (1987) contributed a lively, engaging, concise text that did a superb job of modeling critical thinking for students.

In addition to the aforementioned books, the 1980s brought wellreceived new texts from Darley, Glucksberg, Kamin, and Kinchla (1981); Rathus (1981); Lahey (1983); Roediger, Rushton, Capaldi, and Paris (1984); Carlson (1984); Santrock (1986); Benjamin, Hopkins, and Nation (1987); and Bernstein, Roy, Wickens, and Srull (1988). Thus, psychology entered the 1990s with an excellent collection of introductory textbooks.

\section{HOW INTRODUCTORY TEXTS EVOLVED: EMPIRICAL COMPARISONS}

Despite the dearth of scholarly literature on the history of introductory psychology texts, individuals interested in their evolution have a unique resource available - the books themselves - which, unlike people or events from the past, remain preserved exactly as they were-on library bookshelves. Hence, we set out to identify a representative sample of leading texts from the past 100 years and to analyze how they have changed across the decades. In this section, we report on what we learned from this comparative analysis.

\section{The Sample of Textbooks}

Our intent was to scrutinize a handful of the most widely respected introductory texts from each decade between 1890 and 1990 and then make comparisons across decades. We solicited advice from the fellows $(n=92)$ of Division 26 (History of Psychology) of the American Psychological Association and the surviving past-presidents $(n=30)$ of Division 2 (Teaching of Psychology). Both groups responded to the same questionnaire, which asked them to nominate up to three leading texts from each decade. The definition of "leading" was left to the respondents, who were asked to make nominations only for those decades about which they felt knowledgeable.

Our survey was returned by 31 respondents, many of whom invested considerable time and effort to provide a total of 529 nominations. The $25 \%$ return rate seems reasonable in light of the substantial work required to complete the survey; also, some of our prospective respondents indicated that they did not feel sufficiently well informed to participate. The mean number of books nominated for each decade was 16.27. Many books were nominated in more than one decade. For example, Woodworth's Psychology 
was nominated from the 1920 s through the 1950 s. The most frequently nominated book for each decade is identified in Table 1 by a superscript $a$.

After reviewing our data, we decided to select five texts from the 1890 s and four texts from each subsequent decade for our comparative analysis. Our selections, listed in Table 1, were strongly guided by the number of nominations the books received. However, for some decades, we had to exercise some judgment in selecting the third or fourth text from several books that received roughly equal support. When two or more editions of a selected book were published in a decade, the specific edition chosen was largely determined by the edition we could find.

Given our small sample size and the discretion we exercised in making some selections, Table 1 should not be viewed as a definitive list of the most successful or widely respected introductory texts from each decade (compiling such a list was not our goal). However, we are confident that the books in Table 1 constitute a reasonably representative sample of the leading texts from each decade. All of the quantitative analyses to be discussed are based on this sample.

\section{Measurement of Text Variables}

Our comparative analysis focused on objective features of the texts, in a manner similar to Weiten's (1988) analysis of 43 contemporary introductory texts. The Appendix lists the text variables that we examined and the details of their measurement. We tried to assess a diverse array of variables, including structural parameters (e.g., number of chapters), production qualities (e.g., number of illustrations), pedagogical strategies (e.g., number of learning aids), and substantive matters (e.g., topical coverage). Some of these variables involved easily determined values that could be ascertained exactly (e.g., the number of pages in a book), but most of them involved more complicated estimates based on systematic sampling from each book (e.g., manuscript length in words).

After all assessments of individual books were completed, the data for the books in each decade were averaged. We used these means to assess trends over time. The summary of our findings consists of six sections that focus on trends in topical coverage, topical organization, book size, illustration programs, pedagogical aids, and citations and references.

\section{Topical Coverage}

The percentage of coverage devoted to each of the 15 topical areas listed in the Appendix is charted by decade in Table 2. Although Matarazzo (1987) argued that the core subject matter of introductory texts has remained much the same since the late 19th century, our data indicate that topical coverage has changed considerably over the years. In the early 


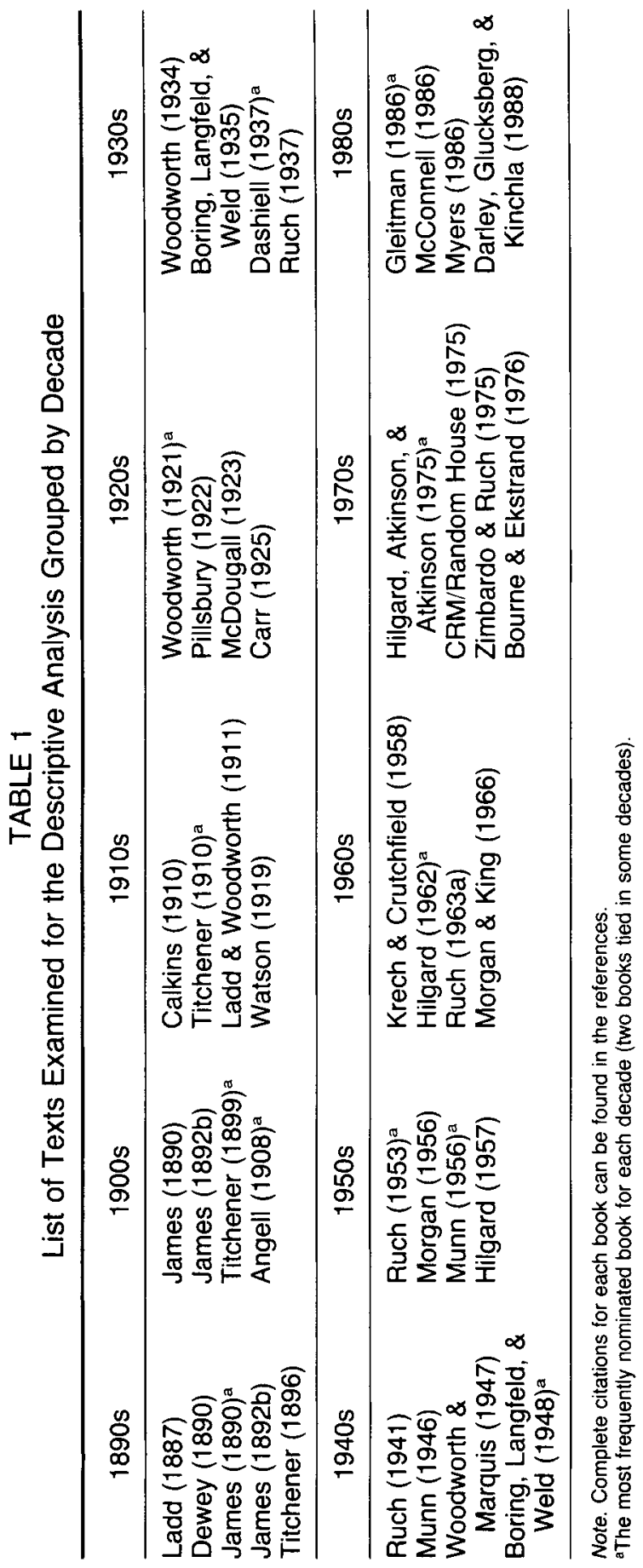




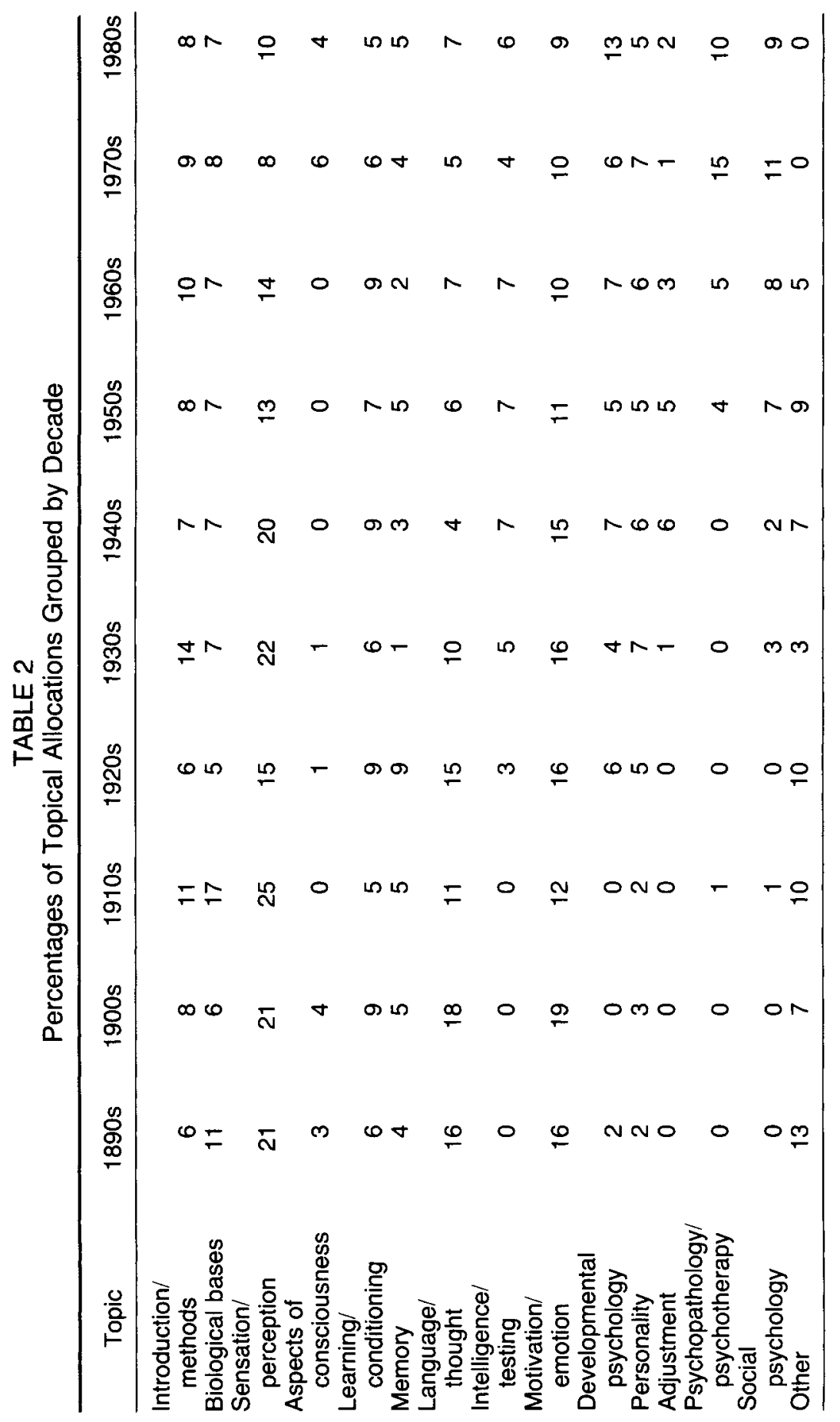


decades, the dominant subjects were biological bases of behavior, sensation/ perception, language/thought, and motivation/emotion. For example, these four topics accounted for $64 \%$ of the coverage in our 1890s sample of books. By contrast, contemporary texts divide their coverage more evenly among more topics. Among the leading topics are several that received little or no coverage in the early books, such as developmental psychology, social psychology, and psychopathology/psychotherapy. In terms of trends over time, the topics basically fall into four groups: (a) those that have declined gradually since the early days, (b) those that have remained relatively stable, (c) those that have attracted increasing attention, and (d) those that have attracted sporadic interest.

Topics that have declined markedly include sensation/perception, language/thought, and motivation/emotion. In the 1980s, these subjects received about half as much coverage as they received in the 1890 s. These decreases are probably attributable to contemporary texts dividing their coverage among more areas rather than to declining interest in the older topics. This interpretation is supported by the fact that sensation/perception and motivation/emotion still ranked among the top five most heavily covered topics in the 1980s. Although today's interest in language and thought is often attributed to the so-called cognitive revolution in the 1950s and 1960 s, these subjects actually have a long history of ample coverage. However, the focus of this coverage has shifted from attention, imagination, concept formation, and reasoning toward psycholinguistics, problem solving, and decision making.

Topics that have received relatively stable coverage over the past 100 years (albeit with some fluctuation from decade to decade) include history, methods, and introductory material; biological bases of behavior; learning; memory; and personality. The space devoted to each of these areas has generally been between $5 \%$ and $9 \%$ throughout the past century.

Topics that have attracted increased attention over the years include development, psychological testing/intelligence, psychopathology/psychotherapy, and social psychology. Development emerged as a fairly standard topic in the 1920s, testing in the 1930s, social psychology in the 1950s, and psychopathology/psychotherapy in the 1960s. In our 1980s sample, these topics accounted for $38 \%$ of the coverage, compared with less than $3 \%$ before the 1920 s.

Subjects that have attracted sporadic interest include aspects of consciousness, adjustment, and various topics in the "other" category. James and other early authors discussed the nature of consciousness, but coverage of consciousness dwindled to virtually nothing for the next six decades. The topic surfaced again in the 1970s and 1980s, but the focus shifted from the nature of consciousness to sleep, dreams, and the effects of drugs, hypnosis, and meditation. Coverage of adjustment was begun by Ruch (1937) and Munn (1946) and peaked in the 1940s, when even more tra- 
ditional texts (e.g., Boring, Langfeld, \& Weld, 1948; Woodworth \& Marquis, 1947) added chapters on frustration, conflict, defense mechanisms, and maladjustment. In recent years, coverage of adjustment has dwindled and the focus has shifted to stress, coping, and health psychology.

The "other" category was included in our analysis to avoid forcing older topics into a modern organizational scheme. What kinds of topics showed up in this category? There was extensive coverage of will-volition and the mind-body question in early decades. Animal behavior surfaced as an independent topic in the 1920s and again in the 1950s. Finally, a hodgepodge of applied psychology topics received sporadic attention over the years, including the psychology of work, vocational development, and study skills. These topics continue to appear in some contemporary texts, but they were not found in our 1970s and 1980s samples.

Several forces appear to have influenced the reshaping of topical coverage. The most obvious consideration is that psychology has expanded its domain of interest, and textbooks reflect this accretion of topics and the resultant diminution of traditional coverage. For example, in an article on the evolution of introductory texts between 1912 and 1922, Kantor (1922) commented on how the field's expansion led to new chapters on behavior, language, learning, and intelligence. Nearly 50 years later, MacLeod (1971) surveyed the history of psychology teaching and noted that "psychology, without having discarded its classic problems, has been reaching out into a multitude of fields, each of which involves a broadening of its subject matter" (p. 246).

Introductory texts' metamorphosis from theoretical treatises to eclectic research reviews also influenced their topical coverage. The topical coverage of early texts by Ladd, James, Titchener, Angell, Watson, and others reflected the authors' special vision of what psychology should study. However, as texts became more eclectic, the determinants of topical coverage began to change. For instance, Wolfle (1942) noted that "the amount known about each topic was used by Boring, Langfeld, and Weld (1935) as a basis for determining the space allotted to each in their text" (p. 694).

Changes in the student population also appear to have influenced shifts in topical coverage. As Morawski (1990) noted, the authors of early texts envisioned their audience as reflective, upper-class gentlemen seeking knowledge for its own sake. However, as higher education in America expanded its reach, the student population shifted toward middle-class youth who viewed a college education as an opportunity to advance their social standing. During the 1920 s and 1930s, students' increasingly pragmatic orientation was documented in numerous studies (Arnold, 1926; Hartmann, 1933; Laird, 1923; Longstaff, 1932; Seward, 1931; Tussing, 1938) that explored students' interests in various psychological topics. These studies consistently showed that students were the most interested in personally practical topics such as personality, mental disorders, social rela- 
tions, and intelligence and the least interested in classic topics such as physiological psychology, sensation, perception, animal behavior, and the mind-body problem (Wolfle, 1942). Eventually, authors such as Ruch (1937, 1941) and Munn (1946) began to take students' pragmatic interests into account and other authors followed suit.

One can also argue that sociocultural events have influenced the subject matter of introductory texts. For example, in the preface to his second edition, Ruch (1941) acknowledged that the specter of world war was one impetus for his emphasis on social problems. In a similar vein, Buxton (1946) and Finger (1954) discussed how World War II contributed to the increasingly personal and practical orientation of introductory texts and courses. Beginning in the 1970s, introductory texts added coverage of psychoactive drugs, human sexuality, and gender issues. The addition of these topics reflected sociocultural trends in America (i.e., the rise of recreational drug use, changes in sexual mores, and the women's movement).

\section{Topical Organization}

Contemporary texts organize topics in a fairly standardized order, as listed under topical allocations in the Appendix. Although there are deviations from this modal organization, the chapter sequence in most modern texts closely approximates the organization depicted in the Appendix. Has this organizational scheme always been the dominant model? Our perusal of leading texts from the past 100 years indicated that the answer is no.

The organizational framework that dominates today moves from molecular, lower order biological processes toward molar, higher order mental and social processes. This approach has been fairly common since the 1890 s. However, previous generations of texts exhibited more idiosyncrasies in organization than do modern texts. Calkins (1910), for instance, buried physiology in the back of her book. In his first edition, Ruch (1937) began with topics such as testing, personality, development, and intelligence, and ended with coverage of sensation and perception, learning, and cognition, and omitted physiology altogether.

Moreover, sharp disparities in topical order were often seen in different editions of the same book. For example, the topical sequence in Woodworth's text underwent sweeping reorganizations in its second, third, and fifth editions (Dallenbach, 1933; McGeoch, 1936; Schlosberg, 1948). Dramatically different arrangements were seen in the three editions of Boring, Langfeld, and Weld's text (Bentley, 1948). This diversity led Ruja (1948) to comment that "there is less uniformity in the organization of elementary textbooks than even in their content" (p. 199). All in all, we found considerable variability in organization among the books from each decade, up through the 1960s. In the 1970s, however, topical sequences began to 
converge, leading Kasschau (1977) to comment on the increasing agreement regarding order of presentation.

What prompted this increasing agreement? One might argue that as the science of psychology "matured," there was a growing consensus about the ideal sequence of topics. We find this hypothesis unlikely in light of widespread comments about the increasing fragmentation of psychology in the 1970s and 1980s (e.g., Altman, 1990). Instead, we suspect that the standardization of topical order is attributable to developments in the world of textbook publishing - specifically, the growing financial risk involved in publishing introductory texts and the resultant reluctance of publishers to deviate from prevailing norms. Thus, the 1970 s brought a growing homogenization (a "black hole of sameness," as one of our respondents put it), which was most readily apparent in increasingly similar organization.

\section{Book Size}

Many contemporary students and professors voice concern about the great length of today's introductory texts. As already noted, texts have increased in size over the years, but just how much? We looked at three size variables: number of chapters, total pages, and manuscript length (in words). As shown in Table 3, the average number of chapters has remained fairly stable, typically ranging between 18 and 22 . However, the average number of pages and average manuscript length have both crept up steadily.

Texts of unwieldy length have been around since the beginning of the century. Indeed, the longest book in our sample, James's Principles of Psychology, was published in 1890. The length of this two-volume, 1,393. page book was approximately 516,000 words. James was apologetic about the book's size, noting in his preface that "the work has grown to a length which no one can regret more than the writer himself" $(1890, p . v)$, and he published a condensed version 2 years later.

However, with regard to length, James's epic was clearly a distant outlier for its time. If James's Principles is omitted, texts from the $1890 \mathrm{~s}$ through the 1930 s averaged about 516 pages and 166,000 words. In the 1980s, these figures swelled to 764 pages and 376,000 words. The increase in average manuscript length was particularly steep in the 1950s and 1960s, when texts began to take on an encyclopedic character.

The explanation for longer texts seems straightforward. Throughout the century, psychologists have been expanding their domain of inquiry and increasing their production of research. Since 1930, the number of articles summarized annually in Psychological Abstracts has increased sixfold. Compared with this explosive growth, doubling the length of introductory texts seems temperate. 


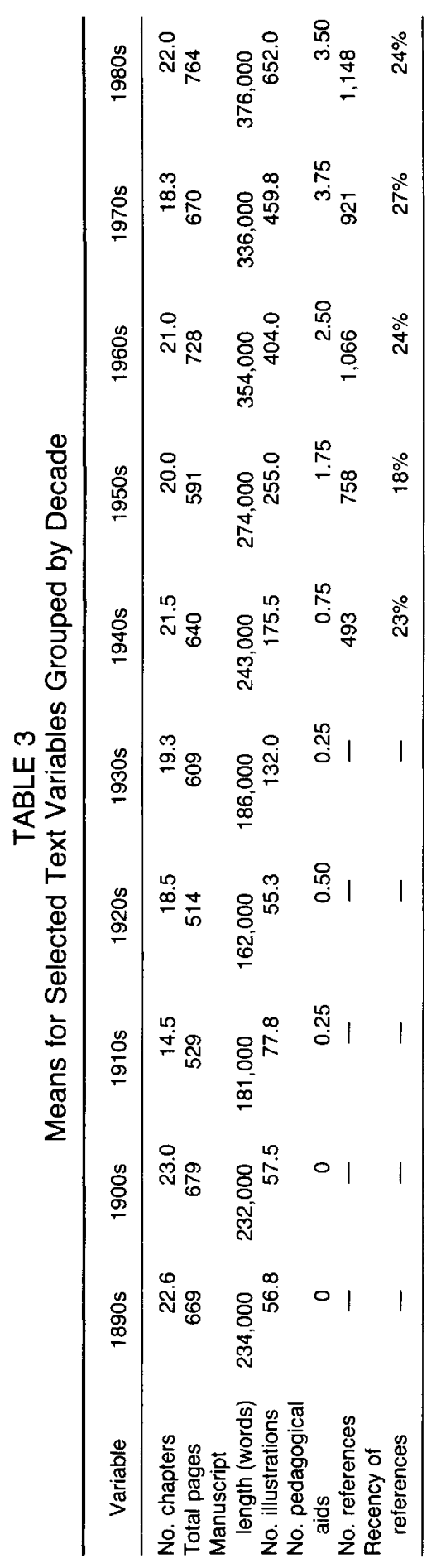




\section{Illustration Programs}

Texts' illustration programs have gradually become more elaborate. The average number of illustrations (figures and photos) in our sample of books increased from 56.8 in the 1890 s to 652 in the 1980 s (see Table 3). Some of this growth was attributable to the increased size of the texts. To take book size into consideration, we computed the average number of illustrations per 100 pages for each decade. This index has also increased dramatically (10-fold).

Photographs have been used since the turn of the century. Until the 1960s, these photos typically appeared as numbered figures, most of which had an obvious instructional purpose (e.g., depicting a memory drum). Ruch's (1937) text was the first to include unnumbered photos that were largely decorative. Although Ruch's (1941) second edition was less profusely illustrated, use of decorative photos grew gradually during the 1940s and 1950 s. Increased reliance on photos was not welcomed in all quarters. For example, in a review of Ruch's (1937) first edition, C. S. Hall (1939) dismissed the photo program as "inconsequential, adding little to the value of the book" (p. 148). Reviewing Hilgard's (1953) first edition, Krech (1954) complained that "recent textbooks have irrelevantly (and irreverently) over-seasoned and over-peppered discussions of psychological concepts with 'text-book cheesecake' - pictures, photographs, and cartoons that add not a whit or a smidgin to such discussions" (p. 562). Despite such negative reactions, decorative photos became a staple of introductory texts by the 1960s. Ironically, both Hall and Krech eventually wrote texts (Krech et al., 1969; Lindzey, Hall, \& Thompson, 1975) that included extensive illustration programs.

Color illustrations were introduced into some books in the 1950s (e.g., Hilgard, 1957). These illustrations were typically limited to a few color plates until 1969, when the publication of Psychology Today ushered in a new era of slick, sophisticated, four-color textbooks. The movement toward profusely illustrated introductory texts was not unique to psychology. Similar trends were seen in other academic disciplines, such as biology and sociology. Elaborate illustration programs were probably stimulated in large part by advances in printing and production technology, which made it easier to use photos and four-color graphics. Also, publishers' increasing commitment to attractive, interesting, student-oriented texts probably contributed to their willingness to spend large sums of money on extravagant graphics.

\section{Pedagogical Aids}

Even rudimentary pedagogical aids, such as chapter summaries, were largely absent from early texts. We checked for the presence of four basic 
learning aids: summaries, review questions, glossaries, and boldface print for technical terms. The average number of these aids found in our sample of texts, charted by decade in Table 3, increased steadily from the 1940s through the 1970s. Review questions first appeared in Titchener (1898), Calkins (1910), and Woodworth (1921). Chapter summaries showed up first in Munn (1946) and Woodworth and Marquis (1947). Chapter outlines were introduced by Ruch (1953) and Munn (1956). Boldface print for technical vocabulary appeared in a few books in the 1960s (e.g., Sanford, 1965).

These learning aids were fairly common by the 1970s, which witnessed the development of several other pedagogical devices, as many authors tried to make their books "user-friendly." Most reviewers welcomed the increased emphasis on pedagogy, although some learning aids were called "gimmicks" (Hines, 1985, p. 488) and were characterized as "disruptive, condescending, and counterproductive" (Vazquez, 1989, p. 471).

\section{Citations and References}

Conventions regarding citations and references have changed considerably since the turn of the century. Between 1890 and 1920, the norm was to use footnotes to cite specific sources, but practices varied. Some books (e.g., Dewey, 1890; James, 1890; Ladd, 1887) provided 500-1,000 such citations, but others (e.g., Titchener, 1896; Watson, 1919) provided none. The practice of supporting specific points with citations declined during the 1920s and 1930s. In most books, footnotes were supplanted by lists of "suggested readings" that were usually placed at the end of each chapter. Books typically contained 200-300 of these recommended resources, which were not clearly linked to text material.

Woodworth (1934) apparently led the movement back to a specific referencing system. Citations in his chapters were numbered consecutively, and the complete references were placed at the end of each chapter. Many other books followed suit in the 1940s, although some continued to provide only lists of suggested readings. By the 1950s, most books adopted a system similar to the American Psychological Association's writing style used today, citing the author and publication year in the text, with full references at the end of the book. Authors in the 1940s and 1950s, however, provided less extensive citations than authors do today. As Table 3 shows, the average number of references found in our sample of books increased dramatically from the 1940s $(M=493)$ through the 1980s $(M=1,148)$.

Although much of this growth could be attributed to the increased volume of psychological research, other factors also appear to be at work. Compared with their predecessors, contemporary authors are much more prone to support every assertion, however trivial or noncontroversial, with citations. Why are modern authors so compulsive about referencing? We 
can only speculate that as research in psychology has burgeoned, many reviewers and teachers have increasingly equated extensive references with excellent scholarship, creating an incentive for authors to compile long lists of references.

To enhance the perception of outstanding scholarship, many contemporary authors tout the recency of their references. To see whether this emphasis on currency was a new phenomenon, we defined "recent" references as those published within 5 years of a book's copyright date and determined the percentage of references that met this criterion for each book in our sample. Table 3 lists the mean percentages of recent references in our sample by decade since the beginning of contemporary referencing (the 1940s). The percentage of recent references has hovered between 18\% and $27 \%$ and has not increased in recent decades. Moreover, if one considers earlier books that provided suggested reading lists or footnotes, it is apparent that recent citations were common long ago. For instance, $48 \%$ of the footnotes in James (1890) and $41 \%$ of the suggested readings in Woodworth (1921) referred to sources that were less than 5 years old. Thus, today's emphasis on recent references is nothing new.

In analyzing citation patterns, we also looked at whom the books cited. We ranked the seven most frequently cited theorists and researchers for each book on the basis of the number of index entries for each person. To combine these rankings for each decade, we assigned points for various ranks ( 7 points for first, 6 for second, 5 for third, etc.) and summed each individual's points. Results of these tabulations are summarized in Table 4, which ranks the seven most frequently cited people for each decade.

These lists reveal that Wundt and Helmholtz were dominant figures in the early decades before giving way to James, who made the top-seven list in more decades (six) than anyone else, including as recently as the 1970s. Freud did not show up among the most heavily cited people until the 1930s, but he has ranked first in citations for the past four decades. Watson (1920s-1940s) and Terman (1930s-1950s) made the top-seven list for three consecutive decades. Others who made the list in several decades include Woodworth, Pavlov, and Skinner. In the past two decades, Freud, Skinner, and Piaget stand out as the most frequently cited individuals. Our results for the 1980s closely resemble those of Knapp (1985), who surveyed a larger sample $(N=24)$ of contemporary texts.

The data in Table 4 suggest that the most frequently cited people in introductory texts tend to be influential theorists rather than prolific researchers. Interestingly, a lag often occurs before a theorist's important work receives heavy coverage in introductory texts. For example, Ebbinghaus, Freud, Adler, Terman, Pavlov, Cannon, Guilford, Skinner, Piaget, Rogers, and Erikson all appear on the most cited list for the first time one to three decades after they began to publish their influential work. 


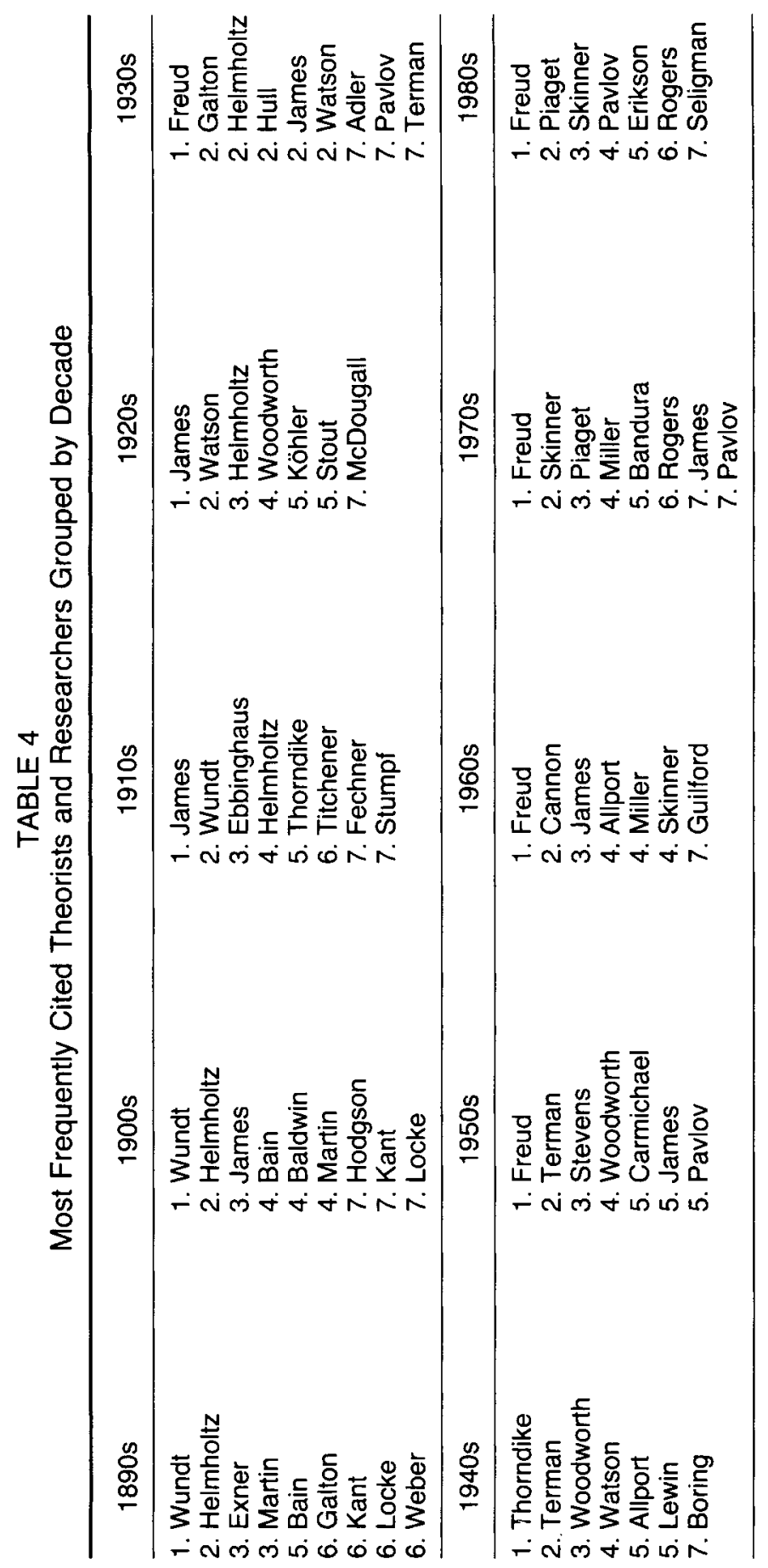




\section{CONCLUSION}

Introductory texts are often viewed by academicians with suspicion and scorn. For instance, as Morawski (1992) noted, "at best, such writing is considered 'second-hand' or contrived knowledge. Scientists from all disciplines jest about the deceptions and inaccuracies - made for the sake of clarity, simplicity, or profit-contained in introductory texts" (pp. 161162). Psychology professors have complained about introductory texts' colloquial language, oversimplification of complex issues, superficial coverage, conceptual and theoretical blandness, and popularization of the field's subject matter almost since the beginning (e.g., Dallenbach, 1922; Ewert, 1937; Hunter, 1939; Rosenberg, 1956).

Authors have made their share of mistakes. In recent years, for example, introductory textbooks have been criticized for misdrawing Pavlov's apparatus (Goodwin, 1991) and Mrs. Cantlie's homunculi diagrams (Griggs, 1988); for misrepresenting the Yerkes-Dodson law (Winton, 1987), Rogers's motivational constructs (Ford \& Maas, 1989), and Watson's study of Little Albert (Harris, 1979; Prytula, Oster, \& Davis, 1977); for distorting key aspects of sociobiology (Herzog, 1986) and Adlerian theory (Silverman \& Corsini, 1984); for confusing the concepts of negative reinforcement and punishment (Morse, 1986); for inaccurately suggesting that researchers have reliably determined the number of neurons in the human brain (Soper $\&$ Rosenthal, 1988); for exaggerating the prevalence of multiple personality disorder and the magnitude of the link between stress and illness (Morse, 1986); and for uncritically reporting unsubstantiated claims about hemispheric specialization, extrasensory perception (Hines, 1985), the effects of stress on "executive monkeys" (McGovern, 1978), and the impact of early intervention on underprivileged children's intelligence (Sommer $\&$ Sommer, 1983).

However, many of these misconceptions were not unique to introductory texts; they were widely accepted in the field as a whole. Given that introductory texts cover hundreds of issues and thousands of studies, critics are bound to find specific points of contention, especially in their areas of expertise. In preparing this chapter, we read book reviews of more than 400 introductory texts. In these reviews, the vast majority of texts were characterized as accurate, scholarly, and current.

Why, then, are introductory texts the object of derision? In part, this attitude may reflect academicians' distaste for commercial enterprises driven by the profit motive. Another prominent consideration is that modern academia holds teaching and related activities (e.g., writing textbooks) in low esteem compared with basic research. As Tyson-Bernstein (1989) put it, "real scholars don't write textbooks" (p. 25). We also suspect that much of the criticism stems from viewing introductory texts as being little more than a series of research reviews. This perspective does not do justice to 
the complex nature of introductory texts, which must serve many masters. This complexity was perhaps explained best in McConnell's (1978) article, "Confessions of a Textbook Writer." McConnell pointed out that introductory texts must meet the needs of five different constituencies:

These five different audiences-students, instructors, peers and colleagues, publishers, and one's inner feelings and needs - make very different and often conflicting demands on the writer of an introductory text. Satisfying them all is something of an impossibility. (p. 167)

The difficulties inherent in writing an introductory text have not gone entirely unappreciated. A number of reviewers, such as Matlin (1983) and Greendlinger (1989), have commented on the challenging nature of the task. One of the more insightful analyses came from McGeoch (1936) in a review of Woodworth's (1934) third edition:

The author of a satisfactory general introduction to psychology is faced with a task of tremendous dimensions. He must present the fundamentals of a subject in which there is still disagreement over what, for the beginning student, the fundamentals are. He must organize the material so that the student is introduced to the field as a single and unified one, but with a minimum of involved and difficult theorizing. If the book is to be used widely, even the implicit theory behind the organization cannot cut too sharply across the theoretical biases of colleagues. He must, withal, take account of recent work in a rapidly moving set of research problems and must write lucidly and interestingly without sacrificing exactness. (p. 178)

In light of these difficulties, it seems shortsighted to evaluate introductory textbooks by the canons of scholarship applied to journal articles.

In general, we believe that psychology's introductory texts have served the discipline well. The influential early books were written by leading theorists and researchers of the time ${ }^{6}$ and, as McKeachie (1968) pointed out, they helped to lure many bright, talented people into psychology. These books defined the boundaries of an emerging science of psychology and mobilized students, psychologists, and ideas in ways that transformed the discipline. Today's texts are less ambitious about shaping the field's evolution, but they chronicle psychology's progress effectively. For the most part, contemporary texts provide engaging, balanced, comprehensive, pedagogically sophisticated, accurate portraits of the field. Some critics might argue that the texts have grown too long, too similar, and too gimmicky,

\footnotetext{
'It is instructive to examine the list of leading introductory texts found in Table 1 . Of the 16 authors listed for the first five decades, 12 were elected president of the American Psychological Association (APA) in an era when this honor was based on scholarly achievement (only 2 of the 17 authors listed for the second five decades served as president of the APA, although the meaning of this comparison is obscured by the increased politicalization of the office).
} 
but on the whole, they do an admirable job of introducing students to the dynamic and exciting discipline of psychology.

\section{REFERENCES}

Abma, J. S. (1974). A little old, a little new. Contemporary Psychology, 19, $732-$ 736.

Allen C. K. (1980). [Review of Psychology and Life (10th ed.)]. Teaching of Psychology, 7, 122.

Altman, I. (1990). Centripetal and centrifugal trends in psychology. In L. Bickman $\&$ H. Ellis (Eds.), Preparing psychologists for the 21st century: Proceedings of the National Conference on Graduate Education in Psychology (pp. 39-64). Hillsdale, NJ: Erlbaum.

Angell, J. R. (1904). Psychology: An introductory study of the structure and function of human consciousness. New York: Holt.

Angell, J. R. (1908). Psychology: An introductory study of the structure and function of human consciousness. New York: Holt.

Angell, J. R. (1936). James Rowland Angell. In C. Murchison (Ed.), A history of psychology in autobiography (Vol. 3, pp. 1-38). Worcester, MA: Clark University Press.

Apple, M. W. (1985). The culture and commerce of the textbook. Journal of Curriculum Studies, 17, 147-162.

Archer, E. J. (1959). The book with the boxes. Contemporary Psychology, 4, 3940.

Arnold, H. J. (1926). What parts of elementary psychology are most interesting to students? Pedagogical Seminary, 33, 729-735.

Atkinson, R. L., Atkinson, R. C., \& Hilgard, E. R. (1979). Introduction to psychology (7th ed.). New York: Harcourt Brace Jovanovich.

Atkinson, R. L., Atkinson, R. C., \& Hilgard, E. R. (1983). Introduction to psychology (8th ed.). New York: Harcourt Brace Jovanovich.

Atkinson, R. L., Atkinson, R. C., Smith, E. E., \& Bem, D. J. (1990). Introduction to psychology (10th ed.). San Diego, CA: Harcourt Brace Jovanovich.

Atkinson, R. L., Atkinson, R. C., Smith, E. E., \& Hilgard, E. R. (1987). Introduction to psychology (9th ed.). San Diego, CA: Harcourt Brace Jovanovich.

Baldwin, J. M. (1889). Handbook of psychology: Vol. 1. Senses and intellect. New York: Holt.

Bare, J. K., \& Guthrie, P. M. (1963). Five elementary texts and one question of identity. Contemporary Psychology, 8, 183-185.

Bartlett, N. R. (1959). The bookstore has been trying to reach you on the phone all morning. Contemporary Psychology, 4, 65-68.

Beardslee, D. C., Hildum, D. C., O’Dowd, D. D., \& Schwartz, S. (1962). Eight 
introductory texts: Marginal differentiations. Contemporary Psychology, 7, 123126.

Benimoff, M. (1990). Eastern Psychological Association: Report of the sixty-first annual meeting. American Psychologist, 45, 1371-1376.

Benjamin, L. T., Jr. (1990, March). William James's dismay with the introductory psychology textbook market of 1890. Paper presented at the meeting of the Eastern Psychological Association, Philadelphia, PA.

Benjamin, L. T., Jr., Hopkins, J. R., \& Nation, J. R. (1987). Psychology. New York: Macmillan.

Bentley, M. (1948). Three Boring-Langfeld-Weld texts. American Journal of Psychology, 61, 589-594.

Bernstein, D. A., Roy, E. J., Wickens, C. D., \& Srull, T. K. (1988). Psychology. Boston: Houghton Mifflin.

Bootzin, R. R., Bower, G. H., Hall, E., \& Crocker, J. (1991). Psychology today: An introduction. New York: McGraw-Hill.

Bootzin, R. R., Bower, G. H., Zajonc, R. B., \& Hall, E. (1986). Psychology today: An introduction (6th ed.). New York: Random House.

Bootzin, R. R., Loftus, E. F., Zajonc, R. B., \& Hall, E. (1983). Psychology today: An introduction (5th ed.). New York: Random House.

Boring E. G. (1950). A history of experimental psychology. New York: AppletonCentury-Crofts.

Boring, E. G., Langfeld, H. S., \& Weld, H. P. (Eds.). (1935). Psychology: A factual textbook. New York: Wiley.

Boring, E. G., Langfeld, H. S., \& Weld, H. P. (Eds.). (1939). Introduction to psychology. New York: Wiley.

Boring, E. G., Langfeld, H. S., \& Weld, H. P. (Eds.). (1948). Foundations of psychology. New York: Wiley.

Bourne, L. E., Jr., \& Ekstrand, B. R. (1973). Psychology: Its principles and meanings. New York: Holt, Rinehart \& Winston.

Bourne, L. E., Jr., \& Ekstrand, B. R. (1976). Psychology: Its principles and meanings (2nd ed.). New York: Holt, Rinehart \& Winston.

Brown, L. T., Collins, W. E., Gladstone, R., Jaynes, W. E., McHale, J. L., Miller, T., Ray, D. D., Sandvold, K. D., \& Scott, W. C. (1971). Traditional but diverse. Contemporary Psychology, 16, 1-5.

Brown, R., \& Herrnstein, R. J. (1975). Psychology. Boston: Little, Brown.

Brozek, J. (1984). David Jayne Hill: Between the old and the new psychology. In J. Brozek (Ed.), Explorations in the history of psychology in the United States (pp. 121-147). Lewisburg, PA: Bucknell University Press.

Bruce, B., Rubin, A., \& Starr, K. (1981). Why readability formulas fail. Urbana, IL: Center for the Study of Reading.

Buel, J. (1938). [Review of Psychology and Life]. Psychological Bulletin, 35, 91-94. 
Buel, J. (1942). [Review of Psychology and Life]. Psychological Bulletin, 39, 262263.

Buxton, C. E. (1946). Planning the introductory psychology course. American Psychologist, 1, 303-311.

Caffrey, B. (1978). [Review of Understanding Human Behavior (2nd ed.)]. Teaching of Psychology, 5, 166-167.

Calkins, M. W. (1901). An introduction to psychology. New York: Macmillan.

Calkins, M. W. (1910). A first book in psychology. New York: Macmillan.

Cameron, E. H. (1911). Three text-books of psychology. Psychological Bulletin, 8, $321-322$.

Campbell, D. E. (1976). [Review of Psychology and Life (9th ed.)]. Teaching of Psychology, 3, 191.

Carlson, N. R. (1984). Psychology: The science of behavior. Boston: Allyn \& Bacon.

Carr, H. A. (1925). Psychology: A study of mental activity. New York: Longmans, Green.

Carr, T. H. (1982). Comparing introductory texts. Contemporary Psychology, 27, $354-358$.

Cattell, J. M. (1929). Psychology in America. Science, 70, 84-95.

Chatman, S. P., \& Goetz, E. T. (1985). Improving textbook selection. Teaching of Psychology, 12, 150-152.

Cone, A. L. (1976). Six luxury models. Contemporary Psychology, 21, 544-548.

Coon, D. (1977). Introduction to psychology: Exploration and application. St. Paul, MN: West.

CRM Books. (1969). Psychology today: An introduction. Del Mar, CA: Author.

CRM Books. (1972). Psychology today: An introduction (2nd ed.). Del Mar, CA: Author.

CRM/Random House. (1975). Psychology today: An introduction (3rd ed.). New York: Author.

CRM/Random House. (1979). Psychology today: An introduction (4th ed.). New York: Author.

Croll, W., \& Moskaluk, S. (1977). Should Flesch counts count? Teaching of Psychology, 4, 48-49.

Dallenbach, K. M. (1922). [Review of Psychology]. American Journal of Psychology, $33,430-435$.

Dallenbach, K. M. (1933). [Review of Psychology]. American Joumal of Psychology, $45,186-188$.

Danziger, K. (1979). The positivist repudiation of Wundt. Joumal of the History of the Behavioral Sciences, 15, 205-230.

Danziger, K. (1985). The origins of the psychological experiment as a social institution. American Psychologist, 40, 133-140. 
Darley, J. M., Glucksberg, S., Kamin, L. J., \& Kinchla, R. A. (1981). Psychology. Englewood Cliffs, NJ: Prentice-Hall.

Darley, J. M., Glucksberg, S., \& Kinchla, R. A. (1988). Psychology (4th ed.). Englewood Cliffs, NJ: Prentice-Hall.

Darwin, C. (1859). On the origin of species. London: Murray.

Darwin, C. (1871). Descent of man. London: Murray.

Dashiell, J. F. (1928). Fundamentals of objective psychology. Boston: Houghton Mifflin.

Dashiell, J. F. (1937). Fundamentals of general psychology. Boston: Houghton Mifflin.

Davidoff, L. L. (1976). Introduction to psychology. New York: McGraw-Hill.

Dewey, J. (1890). Psychology. New York: Harper.

Dewey, J. (1967). John Dewey, the early works, 1882-1898, Vol. 2: 1887, Psychology. Carbondale, IL: Southern Illinois University Press. (Original work published 1887)

Dimmick, F. L. (1940). [Review of Introduction to Psychology]. American Journal of Psychology, 53, 466-468.

Doyle, C. L. (1987). Explorations in psychology. Monterey, CA: Brooks/Cole.

Evans, R. B. (1984). The origins of American academic psychology. In J. Brozek (Ed.), Explorations in the history of psychology in the United States (pp. 17-60). Lewisburg, PA: Bucknell University Press.

Evans, R. B. (1990a). The scientific and psychological positions of E. B. Titchener. In R. Leys \& R. B. Evans (Eds.), Defining American psychology: The correspondence between Adolf Meyer and Edward Bradford Titchener (pp. 1-38). Baltimore, MD: Johns Hopkins University Press.

Evans, R. B. (1990b). William James and his Principles. In M. G. Johnson \& T. B. Henley (Eds.), Reflections on The Principles of Psychology: William James after a century (pp. 11-31). Hillsdale, NJ: Erlbaum.

Evans, R. B. (1991). Introduction: The historical context. In F. H. Burkhardt \& F. Browers (Eds.), William James's Principles of Psychology (pp. xli-xlviii). Cambridge, MA: Harvard University Press.

Ewert, H. (1937). [Review of General Psychology]. Psychological Bulletin, 34, 173174.

Farnsworth, D. F. (1979, October 29). College publishing: The need for reassessment. Publishers Weekly, pp. 46, 51-52.

Fay, J. W. (1939). American psychology before William James. New Brunswick, NJ: Rutgers University Press.

Fernald, L. D., Jr., \& Fernald, P. S. (1978). Introduction to psychology (4th ed.). Boston: Houghton Mifflin.

Fernald, L. D., Jr., \& Fernald, P. S. (1985). Introduction to psychology (5th ed.). Dubuque, IA: William C. Brown.

Finger, F. W. (1954). Textbooks and general psychology. Psychological Bulletin, $51,82-90$. 
Fischer, K. W., \& Lazerson, A. (1977). Managing a book versus plagiarizing it. Teaching of Psychology, 4, 198-199.

Flesch, R. (1948). A new readability yardstick. Journal of Applied Psychology, 32, $221-233$.

Flesch, R. (1951). How to test readability. New York: Harper.

Ford, J. G., \& Maas, S. (1989). On actualizing person-centered theory: A critique of textbook treatments of Rogers's motivational constructs. Teaching of Psychology, 16, 30-31.

Fretz, B. R. (1979). Different strokes or reruns? Contemporary Psychology, 24, 485490.

Furumoto, L. (1991). From "paired associates" to a psychology of self: The intellectual odyssey of Mary Whiton Calkins. In G. A. Kimble, M. Wertheimer, $\&$ C. L. White (Eds.), Portraits of pioneers in psychology (pp. 57-72). Hillsdale, NJ: Erlbaum.

Gazzaniga, M. S. (1973). Fundamentals of psychology: An introduction. New York: Academic Press.

Geldard, F. A. (1936). [Review of Psychology: A Factual Textbook]. American Journal of Psychology, 48, 693-694.

Gerow, J. R. (1981). [Review of Psychology]. Teaching of Psychology, 8, 189.

Gillen, B. (1973). Readability and human interest scores of thirty-four current introductory psychology texts. American Psychologist, 28, 1010-1011.

Gillen, B. (1975). Readability and human interest scores of thirty-two introductory psychology texts: Update and clarification. Teaching of Psychology, 2, 175176.

Gillen, B., Kendall, P. C., \& Finch, A. J., Jr. (1977). Reading ease and human interest scores: A comparison of Flesch scores with subjective ratings. Teaching of Psychology, 4, 39-41.

Giorgi, A. (1990). The implications of James's plea for psychology as a natural science. In M. G. Johnson \& T. B. Henley (Eds.), Reflections on The Principles of Psychology: William James after a century (pp. 63-75). Hillsdale, N]: Erlbaum.

Gleitman, H. (1981). Psychology. New York: Norton.

Gleitman, H. (1986). Psychology (2nd ed.). New York: Norton.

Goodwin, C. J. (1991). Misportraying Pavlov's apparatus. American Journal of Psychology, 104, 135-141.

Gould, S. J. (1988, January). The case of the creeping fox terrier clone. Natural History, pp. 19-20, 22, 24.

Greendlinger, V. (1989). A comparative review of three introductory texts. Contemporary Psychology, 34, 836-838.

Griesinger, W. S., \& Klene, R. R. (1984). Readability of introductory psychology textbooks: Flesch versus student ratings. Teaching of Psychology, 11, 90-91. 
Griggs, R. A. (1988). Who is Mrs. Cantlie and why are they doing those terrible things to her homunculi? Teaching of Psychology, 15, 105-106.

Griggs, R. A. (1990). Introductory psychology texts: Survival of the fittest. Contemporary Psychology, 35, 659-662.

Griggs, R. A., \& Jackson, S. L. (1989). The introductory psychology textbook market: Perceptions of authors and editors. Teaching of Psychology, 16, 6164.

Hall, C. S. (1939). [Review of Psychology and Life]. American Journal of Psychology, $52,148$.

Hall, G. S. (1887). [Review of Elements of Physiological Psychology]. American Journal of Psychology, 1, 159-164.

Hall, G. S. (1891). [Review of The Principles of Psychology]. American Journal of Psychology, 3, 578-591.

Hall, G. S. (1923). Life and confessions of a psychologist. New York: Appleton.

Harris, B. (1979). What ever happened to Little Albert? American Psychologist, $34,151-160$.

Hartmann, G. W. (1933). The measurement of the relative interest value of representative items taught in elementary psychology. Journal of Educational Psychology, 24, 266-282.

Haven, J. (1857). Mental philosophy. Boston: Gould \& Lincoln.

Heatherington, L. (1986). A matter of style. Contemporary Psychology, 31, 374375.

Hebb, D. O. (1958). A textbook of psychology. Philadelphia, PA: W. B. Saunders.

Hebb, D. O. (1966). A textbook of psychology (2nd ed.). Philadelphia, PA: W. B. Saunders.

Henmon, V. A. C. (1912). Physiological and experimental texts. Psychological Bulletin, 9, 239-242.

Herzog, H. A., Jr. (1986). The treatment of sociobiology in introductory psychology textbooks. Teaching of Psychology, 13, 12-15.

Hickok, L. P. (1848). Rational psychology. Auburn, AL: Derby, Miller.

Hickok, L. P. (1854). Empirical psychology. New York: Ivison, Blakeman, Taylor.

Hilgard, E. R. (1953). Introduction to psychology. New York: Harcourt, Brace.

Hilgard, E. R. (1957). Introduction to psychology (2nd ed.). New York: Harcourt, Brace.

Hilgard, E. R. (1962). Introduction to psychology (3rd ed.). New York: Harcourt, Brace \& World.

Hilgard, E. R. (1987). Psychology in America: A historical survey. San Diego, CA: Harcourt Brace Jovanovich.

Hilgard, E. R., \& Atkinson, R. C. (1967). Introduction to psychology (4th ed.). New York: Harcourt, Brace \& World.

Hilgard, E. R., Atkinson, R. C., \& Atkinson, R. L. (1971). Introduction to psychology (5th ed.). New York: Harcourt, Brace \& World. 
Hilgard, E. R., Atkinson, R. C., \& Atkinson, R. L. (1975). Introduction to psychology (6th ed.). New York: Harcourt Brace Jovanovich.

Hill, D. J. (1888). The elernents of psychology. New York: Sheldon.

Hines, T. M. (1985). Four introductory texts. Contemporary Psychology, 30, 487489.

Holt, E. B. (1911). Titchener's psychology. Psychological Bulletin, 8, 25-30.

Hopkins, M. (1878). An outline study of man. New York: Scribner's

Hunter, W. S. (1935). [Review of Psychology: A Factual Textbook]. Psychological Bulletin, 32, 595-599.

Hunter, W. S. (1939). [Review of Introduction to Psychology]. Psychological Bulletin, 36, 784-786.

Jacobs, B. (1984). Are these books really different? Contemporary Psychology, 29, $464-467$.

James, H. (Ed.). (1920). 'The letters of William James (Vol. 1). Boston: Atlantic Monthly.

James, W. (1890). The prizciples of psychology (Vols. 1-2). New York: Holt.

James, W. (1892a). A plec for psychology as natural science. Philosophical Review, $1,146-153$.

James, W. (1892b). Psychology, briefer course. New York: Holt.

Kadushin, C. (1979). The managed text: Prose and qualms. Change, 11, 30-35, 64.

Kagan, J., \& Havemann, ¿. (1968). Psychology: An introduction. New York: Harcourt, Brace \& World.

Kantor, J. R. (1922). The evolution of psychological textbooks since 1912. Psychological Bulletin, 19, 429-442.

Kasschau, R. A. (1973). 17 inches of (mixed) pleasure. Contemporary Psychology, $18,617-623$.

Kasschau, R. A. (1974). Review of Understanding Human Behavior]. Teaching of Psychology, 1, 42-43.

Kasschau, R. A. (1977). 22.1 centimeters of (mixed) pleasure: Psigns of the times. Contemporary Psychology, 22, 505-508.

Kasschau, R. A., \& Camp, C. J. (1976). [Review of Psychology Today: An Introduction (3rd ed.)]. Teaching of Psychology, 3, 148-149.

Kendler, H. H. (1963). Basic psychology. New York: Appleton-Century-Crofts.

Kendler, H. H., \& Kencler, T. S. (1971). Basic psychology: Brief edition. New York: Appleton-Century-Crofts.

Kimble, G. A. (1956). Pinciples of general psychology. New York: Ronald Press.

Kimble, G. A., \& Garmezy, N. (1963). Principles of general psychology (2nd ed.). New York: Ronald Press.

Kimble, G. A., \& Garmezy, N. (1968). Principles of general psychology (3rd ed.). New York: Ronald Press. 
Knapp, T. J. (1985). Who's who in American introductory psychology textbooks: A citation study. Teaching of Psychology, 12, 15-17.

Krech, D. (1954). [Review of Introduction to Psychology]. American Journal of Psychology, 67, 561-565.

Krech, D., \& Crutchfield, R. S. (1958). Elements of psychology. New York: Knopf.

Krech, D., Crutchfield, R. S., \& Livson, N. (1969). Elements of psychology (2nd ed.). New York: Knopf.

Krech, D., Crutchfield, R. S., Livson, N., Wilson, W. A., Jr., \& Parducci, A. (1982). Elements of psychology (4th ed.). New York: Knopf.

Külpe, O. (1909). Outlines of psychology: Based upon the results of experimental investigation (3rd ed., E. B. Titchener, Trans.). New York: Macmillan. (Original work published 1893)

Ladd, G. T. (1887). Elements of physiological psychology. New York: Scribner's.

Ladd, G. T. (1890). Outlines of physiological psychology. New York: Scribner's.

Ladd, G. T. (1892). Psychology as so-called natural science. Philosophical Review, $1,24-53$.

Ladd, G. T. (1894a). Primer of psychology. New York: Longmans, Green.

Ladd, G. T. (1894b). Psychology: Descriptive and explanatory. New York: Scribner's.

Ladd, G. T. (1898). Outlines of descriptive psychology. New York: Scribner's.

Ladd, G. T., \& Woodworth, R. S. (1911). Elements of physiological psychology (2nd ed.). New York: Scribner's.

Lahey, B. B. (1983). Psychology: An introduction. Dubuque, IA: William C. Brown.

Laird, D. A. (1923). Reaction of college students to mental hygiene. Mental Hygiene, 7, 271-276.

Landrigan, D. T., \& Palladino, J. J. (1974). A reply to Gillen. American Psychologist, 29, 571-572.

Lange, B. (1982). Readability formulas: Second looks, second thoughts. Reading Teacher, 35, 858-861.

Lazarus, R. S. (1974). The riddle of man: An introduction to psychology. Englewood Cliffs, NJ: Prentice-Hall.

Lefton, L.A. (1979). Psychology. Boston: Allyn \& Bacon.

Levin, M. J. (1978). Psychology: A biological approach. New York: McGraw-Hill.

Lindzey, G., Hall, C., \& Thompson, R. F. (1975). Psychology. New York: Worth.

Longstaff, H.P. (1932). Analysis of some factors conditioning learning in general psychology: Parts I and II. Journal of Applied Psychology, 16, 9-48, 131-166.

MacLeod, R. B. (1971). The teaching of psychology. American Psychologist, 26, $245-249$.

Malott, R. W., \& Whaley, D. L. (1976). Psychology. Kalamazoo, MI: Behaviordelia, and New York: Harper's College Press.

Marquis, D. G. (1938). [Review of Fundamentals of General Psychology]. Psychological Bulletin, 35, 95-99. 
Matarazzo, J. D. (1987). There is only one psychology, no specialties, but many applications. American Psychologist, 42, 893-903.

Matlin, M. W. (1983). Introducing psychology. Contemporary Psychology, 28, 440443.

Maxwell, M. (1978). Readability: Have we gone too far? Joumal of Reading, 21, $525-530$.

McConnell, J. V. (1974). Understanding human behavior, New York: Holt, Rinehart $\&$ Winston.

McConnell, J. V. (1977). Understanding human behavior (2nd ed.). New York: Holt, Rinehart \& Winston.

McConnell, J. V. (1978). Confessions of a textbook writer. American Psychologist, $33,159-169$.

McConnell, J. V. (1980). Understanding human behavior (3rd ed.). New York: Holt, Rinehart $\&$ Winston.

McConnell, J. V. (1983). Understanding human behavior (4th ed.). New York: Holt, Rinehart \& Winston.

McConnell, J. V. (1986). Understanding human behavior (5th ed.). New York: Holt, Rinehart \& Winston.

McConnell, J. V. (1989). Understanding human behavior (6th ed.). New York: Holt, Rinehart \& Winston.

McCosh, J. (1886). Psychology: The cognitive powers. New York: Scribner's.

McCosh, J. (1887). Psychology: The motive powers. New York: Scribner's.

McDougall, W. (1912). Psychology: The study of behavior. London: Oxford University Press.

McDougall, W. (1923). Outline of psychology. London: Methuen.

McGeoch, J. A. (1936). [Review of Psychology]. American Journal of Psychology, $48,178-179$.

McGovern, L. P. (1978). The executive monkeys: Fact and fiction in introductory psychology texts. Teaching of Psychology, 5, 36-37.

McKeachie, W. J. (1968). Psychology at age 75: The psychology teacher comes into his own. American Psychologist, 23, 551-557.

McKeachie, W. J., \& Doyle, C. L. (1966). Psychology. Reading, MA: AddisonWesley.

McKeachie, W. J., \& Doyle, C. L. (1972). Psychology: The short course. Reading, MA: Addison-Wesley.

McKenna, V. V. (1967). Big book; small book: The search for unity and relevance. Contemporary Psychology, 12, 58-62.

McMahon, F. B. (1977). The psychology textbook network. Teaching of Psychology, 4, 196-198.

Meyer, M. (1911). The fundamental laws of human behavior. Boston: Badger. 
Mills, E. S. (1969). George Trumbull Ladd: Pioneer American psychologist. Cleveland, $\mathrm{OH}$ : Case Western Reserve University Press.

Mills, E. S. (1974). George Trumbull Ladd: The great textbook writer. Journal of the History of the Behavioral Sciences, 10, 299-303.

Morawski, J. G. (1990, June). Books in science: Introductory texts and the formations of American psychology. Paper presented at the meeting of the Cheiron Society, Westfield State College, Westfield, MA.

Morawski, J. G. (1992). There is more to our history of giving: The place of introductory textbooks in American psychology. American Psychologist, 47, $161-169$.

Morgan, C. T. (1956). Introduction to psychology. New York: McGraw-Hill.

Morgan, C. T. (1974). A brief introduction to psychology. New York: McGraw-Hill.

Morgan, C. T., \& King, R. A. (1966). Introduction to psychology (3rd ed.). New York: McGraw-Hill.

Morse, D. L. (1986). Two views of psychology. Contemporary Psychology, 31, 984985.

Munn, N. L. (1946). Psychology: The fundamentals of human adjustment. Boston: Houghton Mifflin.

Munn, N. L. (1951). Psychology: The fundamentals of human adjustment (2nd ed.). Boston: Houghton Mifflin.

Munn, N. L. (1956). Psychology: The fundamentals of human adjustment (3rd ed.). Boston: Houghton Mifflin.

Munn, N. L. (1961). Psychology: The fundamentals of human adjustment (4th ed.). Boston: Houghton Mifflin.

Munn, N. L. (1962). Introduction to psychology (abridged edition of Psychology: The fundamentals of human adjustment, 4th ed.). Boston: Houghton Mifflin.

Munn, N. L. (1966). Psychology: The fundamentals of human adjustment (5th ed.). Boston: Houghton Mifflin.

Munn, N. L., Fernald, L. D., Jr., \& Fernald, P. S. (1969). Introduction to psychology (2nd ed.). New York: Houghton Mifflin.

Munn, N. L., Fernald, L. D., Jr., \& Fernald, P. S. (1972). Introduction to psychology (3rd ed.). Boston: Houghton Mifflin.

Münsterberg, H. (1915). Psychology: General and applied. New York: Appleton.

Mussen, P., Rosenzweig, M. R., Aronson, E., Elkind, D., Feshbach, S., Geiwitz, J., Glickman, S. E., Murdock, B. B., Jr., Wertheimer, M., \& Harvey, L. O., Jr. (1977). Psychology: An introduction. Lexington, MA: Heath.

Myers, D. G. (1986). Psychology. New York: Worth.

O'Donnell, J. M. (1986). The origins of behaviorism: American psychology, 18701920. New York: New York University Press.

Ofiesh, G. D. (1959). The history, development, present status and purpose of the first (introductory) course in psychology in American undergraduate education. Unpublished doctoral dissertation, University of Denver, Denver, CO. 
Ogdon, D. P. (1954). Flesch counts of eight current texts for introductory psychology. American Psychologist, 9, 143-148.

Papalia, D. E., \& Olds, S. W. (1985). Psychology. New York: McGraw-Hill.

Pfeiffer, K. (1980). [Review of Introduction to Psychology (7th ed.)]. Teaching of Psychology, 7, 119.

Pillsbury, W. B. (1911). Essentials of psychology. New York: Macmillan.

Pillsbury, W. B. (1922). The fundamentals of psychology. New York: Macmillan.

Pillsbury, W. B. (1932). Walter B. Pillsbury. In C. Murchison (Ed.), A history of psychology in autobiography (Vol. 2, pp. 265-295). Worcester, MA: Clark University Press.

Pollio, H. R. (1981). Behavior and existence: An introduction to empirical humanistic psychology. Monterey, CA: Brooks/Cole.

Popplestone, J. A. (1978). Once more, dear friends. Contemporary Psychology, 23, $142-151$.

Prytula, R. E., Oster, G. D., \& Davis, S. F. (1977). The "rat rabbit" problem: What did John B. Watson really do? Teaching of Psychology, 4, 44-46.

Quereshi, M. Y., \& Sackett, P. R. (1977). An updated content analysis of introductory psychology textbooks. Teaching of Psychology, 4, 25-30.

Quereshi, M. Y., \& Zulli, M. R. (1975). A content analysis of introductory psychology textbooks. Teaching of Psychology, 2, 60-65.

Rathus, S. A. (1981). Psychology. New York: Holt, Rinehart \& Winston.

Rauch, F. A. (1840). Psychology. New York: Dodd, Mead.

Roback, A. A. (1964). History of American psychology. New York: Collier.

Robinson, F. P. (1970). Effective study. New York: Harper \& Row.

Robinson, P. W., \& Higbee, K. L. (1978). Publishing a textbook: Advice from authors and publishers. Teaching of Psychology, 5, 175-181.

Roediger, H. L., Ill, Rushton, J. P., Capaldi, E. D., \& Paris, S. G. (1984). Psychology. Boston: Little, Brown.

Rosenberg, M. J. (1956). Science? Contemporary Psychology, 1, 196-197.

Ruch, F. L. (1937). Psychology and life. Glenview, IL: Scott, Foresman.

Ruch, F. L. (1941). Psychology and life (2nd ed.). Glenview, IL: Scott, Foresman.

Ruch, F. L. (1948). Psychology and life (3rd ed.). Glenview, IL: Scott, Foresman.

Ruch, F. L. (1953). Psychology and life (4th ed.). Glenview, IL: Scott, Foresman.

Ruch, F. L. (1958). Psychology and life (5th ed.). Glenview, IL: Scott, Foresman.

Ruch, F. L. (1963a). Psychology and life (6th ed.). Glenview, IL: Scott, Foresman.

Ruch, F. L. (1963b). Psychology and life (brief 6th ed.). Glenview, IL: Scott, Foresman.

Ruch, F. L. (1967a). Psychology and life (7th ed.). Glenview, IL: Scott, Foresman.

Ruch, F. L. (1967b). Psychology and life (brief 7th ed.). Glenview, IL: Scott, Foresman. 
Ruch, F. L., \& Zimbardo, P. G. (1971). Psychology and life (8th ed.). Glenview, IL: Scott, Foresman.

Rudman, H. C. (1990). Corporate mergers in the publishing industry: Helpful or intrusive? Educational Researcher, 19(1), 14-20.

Ruja, H. (1948). The order of topics in general psychology. American Psychologist, $3,199-202$.

Sanford, F. H. (1965). Psychology: A scientific study of man (2nd ed.). Belmont, CA: Wadsworth.

Santrock, J. W. (1986). Psychology: The science of mind and behavior. Dubuque, IA: William C. Brown.

Schlosberg, H. (1948). [Review of Psychology]. Psychological Bulletin, 45, 89-90.

Schmucker, S. S. (1842). Psychology. New York: Harper.

Seward, G. H. (1931). Students' reactions to a first course in psychology. Journal of Applied Psychology, 15, 512-524.

Sexton, V. S. (1977). Old and new: There's one for you. Contemporary Psychology, $22,190-192$.

Silverman, N. N., \& Corsini, R. J. (1984). Is it true what they say about Adler's individual psychology? Teaching of Psychology, 11, 188-189.

Smith, S. S. (1812). Lectures on moral and political philosophy (Vols. 1-2). Trenton, NJ: Fenton.

Sommer, R., Estabrook, M., \& Horobin, K. (1988). Faculty awareness of textbook prices. Teaching of Psychology, 15, 17-21.

Sommer, R., \& Sommer, B. A. (1983). Mystery in Milwaukee: Early intervention, IQ, and psychology textbooks. American Psychologist, 38, 982-985.

Soper, B., \& Rosenthal, G. (1988). The number of neurons in the brain: How we report what we do not know. Teaching of Psychology, 15, 153-156.

Taylor, E. (1990). New light on the origin of William James's experimental psychology. In M. G. Johnson \& T. B. Henley (Eds.), Reflections on The Principles of Psychology: William James after a century (pp. 33-61). Hillsdale, NJ: Erlbaum.

Thomas, J. M. (1984). Four introductions to psychology. Contemporary Psychology, $29,629-632$.

Titchener, E. B. (1896). An outline of psychology. New York: Macmillan.

Titchener, E. B. (1897). An outline of psychology (2nd ed.). New York: Macmillan.

Titchener, E. B. (1898). A primer of psychology. New York: Macmillan.

Titchener, E. B. (1899). An outline of psychology (3rd ed.). New York: Macmillan.

Titchener, E. B. (1901-1905). Experimental psychology: A manual of laboratory practice ( 2 vols. in 4). New York: Macmillan.

Titchener, E. B. (1910). A text-book of psychology. New York: Macmillan.

Titchener, E. B. (1915). A beginner's psychology. New York: Macmillan. 
Titchener, E. B. (1921). George Trumbull Ladd. American Journal of Psychology, 32,600 .

Tussing, L. (1938). What students want from the elementary course in psychology. Journal of Applied Psychology, 20, 633-658.

Tyson-Bernstein, H. (1989). The academy's contribution to textbook impoverishment. Education Digest, 54(6), 25-28.

Upham, T. C. (1827). Elements of intellectual philosophy. Portland, OR: Shirley \& Hyde.

Upham, T. C. (1831). Elements of mental philosophy (Vols. 1-2). Boston: Wells $\&$ Lily.

Vaughan, W. F. (1936). General psychology. Garden City: NY: Doubleday.

Vazquez, C. A. (1989). Pedagogy versus substance. Contemporary Psychology, 34, $470-473$.

Vernon, W. M. (1974). Introductory psychology: A mastery coursebook with performance objectives. Chicago: Rand McNally.

Wade, C., \& Tavris, C. (1987). Psychology. New York: Harper \& Row.

Walls, J. W. (1980). [Review of Psychology Today: An Introduction (4th ed.)]. Teaching of Psychology, 7, 120-121.

Watson, J. B. (1911). [Review of A Text-Book of Psychology]. American Journal of Psychology, 22, 313-316.

Watson, J. B. (1913). Psychology as the behaviorist views it. Psychological Review, $20,158-177$.

Watson, J. B. (1919). Psychology from the standpoint of a behaviorist. Philadelphia, PA: Lippincott.

Wayland, F. (1854). Elements of intellectual philosophy. Boston: Phillips, Sampson.

Webb, W. B. (1991). History from our textbooks: Boring, Langfeld, and Weld's introductory texts (1935-1948+). Teaching of Psychology, 18, 33-35.

Weiner, B., Runquist, W., Runquist, P. A., Raven, B. H., Meyer, W. J., Leiman, A., Kutscher, C. L., Kleinmuntz, B., \& Haber, R. N. (1977). Discovering psychology. Chicago: Science Research Associates.

Weiten, W. (1988). Objective features of introductory psychology textbooks as related to professors' impressions. Teaching of Psychology, 15, 10-16.

Wight, R. D. (1991). Selling a psychobiologist: Yerkes, Münsterberg, academic politics, and an anomalous textbook. Manuscript submitted for publication.

Winston, A. S. (1988). Cause and experiment in introductory psychology: An analysis of R. S. Woodworth's textbooks. Teaching of Psychology, 15, 79-83.

Winston, A. S. (1990). Robert Sessions Woodworth and the "Columbia bible": How the psychological experiment was redefined. American Journal of Psychology, 103, 391-401.

Winton, W. M. (1987). Do introductory textbooks present the Yerkes-Dodson law correctly? American Psychologist, 42, 202-203. 
Wolfle, D. (1942). The first course in psychology. Psychological Bulletin, 39, 685712.

Woodworth, R. S. (1921). Psychology: A study of mental life. New York: Holt.

Woodworth, R. S. (1929). Psychology (2nd ed.). New York: Holt.

Woodworth, R. S. (1934). Psychology (3rd ed.). New York: Holt.

Woodworth, R. S. (1938). Experimental psychology. New York: Holt.

Woodworth, R. S. (1940). Psychology (4th ed.). New York: Holt.

Woodworth, R. S., \& Marquis, D. G. (1947). Psychology (5th ed.). New York: Holt.

Woodworth, R. S., \& Schlosberg, H. (1954). Experimental psychology (2nd ed.). New York: Holt.

Wortman, C. B., \& Loftus, E. F. (1981). Psychology. New York: Knopf.

Yerkes, R. M. (1911). Introduction to psychology. New York: Holt.

Zimbardo, P. G. (1979). Psychology and life (10th ed.). Glenview, IL: Scott, Foresman.

Zimbardo, P. G. (1985). Psychology and life (11th ed.). Glenview, IL: Scott, Foresman.

Zimbardo, P. G. (1988). Psychology and life (12th ed.). Glenview, IL: Scott, Foresman.

Zimbardo, P. G. (1992). Psychology and life (13th ed.). New York: HarperCollins.

Zimbardo, P. G., \& Ruch, F. L. (1975). Psychology and life (9th ed.). Glenview, IL: Scott, Foresman. 


\section{APPENDIX}

\section{DESCRIPTION OF TEXT VARIABLES}

1. Topical allocations. Each book was inspected to determine the number of chapters devoted to each of 15 topical areas. The categorization of chapters was based on their dominant topic. When necessary, chapters were divided in half and assigned to two topical areas. The number of chapters on each topic was divided by the total number of chapters to estimate the proportion of coverage devoted to each topic. Appendixes were included in these analyses only if they were comparable in size to the book's chapters. The topical areas were organized as follows:
a. Introduction/history/methods,
b. Biological bases of behavior,
c. Sensation/perception,
d. Aspects of consciousness,
e. Learning/conditioning,
f. Memory,
g. Language/thought
h. Intelligence/psychological testing,
i. Motivation/emotion,
j. Developmental psychology,
k. Personality,
1. Adjustment,
m. Psychopathology/psychotherapy,
n. Social psychology, and
o. Other.

2. Number of chapters. The number of chapters in each book was recorded.

3. Total pages. The total number of pages in each book was recorded, including appendixes, references, glossaries, indexes, and all material that followed the main text (but not front matter).

4. Manuscript length. An estimate of the length of the manuscript (excluding front matter, appendixes, references, etc.) in words was made by multiplying the number of words that fit on a full page (based on the page closest to $p .100$ that contained nothing but text) by the number of pages of text and then subtracting a portion of this number to allow for illustrations (results were rounded to the nearest 1,000 words). The proportion subtracted was determined individually for each book on the basis of the amount of space devoted to illustrations in a sample chapter (chapter 8 in each book).

5. Number of illustrations. The number of figures and photographs in chap- 
ters 2, 6, and 10 were counted and averaged. This average was multiplied by the number of chapters to estimate the total number of illustrations in each book. In older books, in which the figures were numbered consecutively across chapters, the last figure was found to determine the number of figures (the number of photographs was still estimated by examining chapters 2,6 , and 10 ).

6. Number of pedagogical aids. Each book was checked for the presence of four pedagogical aids: chapter outlines, chapter summaries, glossaries, and boldface print for technical terms. The total number of these aids incorporated into each book was recorded.

7. Number of references. The average number of references found on the first four full pages of the references section was multiplied by the number of pages of references to estimate the total number of references cited. If a book's references were organized by chapter, the estimate of total references was based on the average number of references found in the first four chapters.

8. Recency of references. The sample of references used to estimate the total number of references was examined to estimate the percentage of references that were "recent" (published within 5 years of the text's copyright date).

9. Most frequently cited theorists and researchers. The index of each book was inspected to determine the number of index entries for various theorists and researchers. The seven people cited most frequently were listed in rank order. 